\title{
Experimental validation of a kinetic multi-component mechanism in a wide HCCI engine operating range for mixtures of n-heptane, iso-octane and toluene: influence of EGR parameters
}

\author{
Hatim Machrafi*, Simeon Cavadias \\ LGPPTS, Ecole Nationale Supérieure de Chimie de Paris / Université Pierre et Marie Curie (Paris 6), 11, rue de \\ Pierre et Marie Curie, 75231 Paris Cedex 05, France, Tel.: +33 144276718
}

\begin{abstract}
The parameters that are present in Exhaust Gas Recirculation (EGR) are believed to provide an important contribution to control the auto-ignition process of the Homogeneous Charge Compression Ignition (HCCI) in an engine. For the investigation of the behaviour of the autoignition process, a kinetic multi-component mechanism has been developed in former work, containing 62 reactions and 49 species for mixtures of n-heptane, iso-octane and toluene. This paper presents an experimental validation of this mechanism, comparing the calculated pressure, heat release, ignition delays and $\mathrm{CO}_{2}$ emissions with experimental data performed on a HCCI engine. The validation is performed in a broad range of EGR parameters by varying the dilution by $\mathrm{N}_{2}$ and $\mathrm{CO}_{2}$ from 0 to $46 \mathrm{vol} \%$, changing the EGR temperature from 30 to $120^{\circ} \mathrm{C}$, altering the addition of $\mathrm{CO}$ and $\mathrm{NO}$ from 0 to $170 \mathrm{ppmv}$ and varying the addition of $\mathrm{CH}_{2} \mathrm{O}$ from 0 to 1400 ppmv. These validations were performed respecting the HCCI conditions for the inlet temperature and the equivalence ratio. The results showed that the mechanism is validated experimentally in dilution ranges going up to $21-30 \mathrm{vol} \%$, depending on the species of dilution and over the whole range of the EGR temperature. The mechanism is validated over the whole range of $\mathrm{CO}$ and $\mathrm{CH}_{2} \mathrm{O}$ addition. As for the addition of $\mathrm{NO}$, the mechanism is validated quantitatively up to $50 \mathrm{ppmv}$ and qualitatively up to 170 ppmv.
\end{abstract}


Keywords: EGR Dilution, Minor chemical species, Combustion, Kinetics, Computational chemistry, HCCI auto-ignition, Experimental validation

\section{Introduction}

In order to reduce the fuel consumption and the production of harmful exhaust gases, solutions have been proposed regarding alternative fuels and post-treatment. Another point of view is to find an alternative combustion mode having considerably better functionalities and characteristics than the present conventional internal combustion engines, such as the sprak ignition engine (gasoline) and the compression ignition engine (diesel). Such a combustion mode should also contribute to a significant reduction of the emission of $\mathrm{CO}_{2}$. The combustion mode Homogeneous Charge Compression Ignition (HCCI) is presented to be a good solution. HCCI can be defined as a premixed, lean burn combustion process, preceded by a homogeneous air/fuel port-injection. The HCCI engine generally runs on a lean, diluted mixture of fuel, air and combustion products, which is not ignited by a spark but by compression auto-ignition instead. Using a lean burn combustion process at lower temperatures and a premixed air-fuel mixture, the HCCI combustion allows for a higher thermal efficiency, less $\mathrm{NO}_{\mathrm{x}}$ emissions and less particulate-matter emissions [1] than conventional SI and diesel engines. Several works [2-5] have been presented, investigating this auto-ignition for many compounds. A great part of these investigations use the so-called Primary Reference Fuels (PRF) [6-10] such as iso-octane and n-heptane. To investigate the behaviour of the auto-ignition process, one may vary parameters such as the inlet temperature, the equivalence ratio or the compression ratio. Another interesting parameter for the autoignition analysis is the effect of exhaust gas re-circulation (EGR). The effect that EGR can have on HCCI combustion is in a dynamic sense. The engine mostly operates at a constant compression ratio (or changing only slightly), reacting relatively slow to a change in the inlet 
temperature, needs a certain equivalence ratio to meet power requirements and mostly runs on one particular fuel. The effect of EGR, however, can be used and changed constantly whenever needed. Therefore it enjoys much attention, being promising to solve the problem of the auto-ignition control [11-15]. Gauthier et al. [16] performed experiments with the combustion of gasoline (octane number 87 ) and a surrogate (63 vol\% iso-octane, $20 \mathrm{vol} \%$ toluene, $17 \mathrm{vol} \% \mathrm{n}$-heptane) in a pressure range of $15-20 \mathrm{~atm}$, with a few select conditions in the 45-60 atm in a shock tube. For a pressure of 20 atm at an equivalence ratio of 1,0 , Gauthier et al. found that an increase in the EGR ratios until $30 \%$ did increase the ignition delay, due to dilution. The increase was more significant at lower temperatures. The effect of trapped hot EGR has a different influence due to the thermal and chemical effects it encompasses. Chen et al. [17] studied this effect using HCCI combustion in internal combustion engines, fuelled with methane. The components of this hot EGR consisted of (5 $\% \mathrm{CO}_{2}, 15,5 \% \mathrm{H}_{2} \mathrm{O}, 0,5 \% \mathrm{O}_{2}$, and $79 \% \mathrm{~N}_{2}$ ). Chen et al. showed that the addition of hot EGR comprised three factors: the thermal factor, the dilution factor and the chemical factor. The thermal factor enhanced (by the high temperature of the hot EGR) the ignition by decreasing the ignition delay. The species $\mathrm{CO}_{2}, \mathrm{~N}_{2}$ and $\mathrm{H}_{2} \mathrm{O}$ increased the ignition delay by dilution. The species $\mathrm{O}_{2}$ also had the same effect. However, different from all other aforementioned components, $\mathrm{O}_{2}$ is part of the combustion reactant. Increasing its concentration will improve the fuel oxidation reaction and therefore accelerate the fuel autoignition reactions. So, the overall effect of the hot EGR depends on the temperature of the EGR and its dilution accompanied by chemical effects $[\mathbf{1 7 , 1 8}]$. Apparently, the effect of EGR on HCCI combustion can be divided into three parts: a dilution effect (inert gasses present in the EGR) $[\mathbf{1 9 , 2 0}$, a thermal effect (heat exchange, thermal loss to the wall, EGR ratio mixture quality, EGR temperature) [15] and a chemical effect [21-25]. The thermal and dilution effect can be considered as inert. It is true that nitrogen, for instance, can participate into the 
formation of $\mathrm{NO}_{\mathrm{x}}$ species. However, the formation of $\mathrm{NO}_{\mathrm{x}}$ has hardly been observed for HCCI conditions and therefore nitrogen can be considered inert. The difference between the diluting effect and the chemical effect is that the former has no significant chemical activity, whilst the latter does. The diluting effect influences the auto-ignition process, by influencing directly the concentrations along with the kinetics $[\mathbf{1 9 , 2 0 ]}$. With the thermal effect one can influence the overall kinetics directly by the reaction rates. The chemical effect, however, is more complex. It not only influences the overall kinetics, but it also can change a specific reaction path [21-23]. This makes this effect particularly interesting for the investigation of the auto-ignition process and is therefore discussed in this paper.

This investigation can be facilitated by using kinetic mechanisms, which can be an important tool, especially of a reduced form [26-29]. Performing a parametrical analysis on autoignition requires kinetic models of low dimensionality. In this way, a wide range of calculations can be made within a short period of computing time. A reduced kinetic mechanism representing the auto-ignition of n-heptane, iso-octane and toluene, containing 62 reactions and 49 species, has been developed and validated numerically in previous work [30], called the surrogate mechanism and presented in table 1. Before such a kinetic mechanism can be used to study the influence of EGR parameters on the auto-ignition, such a mechanism should be validated over a broad range within HCCI engine operating ranges. Therefore, the aim of this paper is to validate experimentally the reduced kinetic mechanism with the use of a CFR engine, adapted to HCCI operating conditions, for some important EGR parameters. The dilution part will be represented by $\mathrm{N}_{2}$ and $\mathrm{CO}_{2}$, which are two gases largely present in the exhaust gases having different heat capacities. This also allows showing the influence of the heat capacity on the effect of the dilution. The dilution is varied between 0 and $46 \mathrm{vol} \%$. The thermal part is represented by the EGR temperature, altering it from 30 to 
$120^{\circ} \mathrm{C}$. As for the chemical part, three kinds of species have been chosen. The first one, CO, represents species stemming from incomplete combustion, a possible inconvenience of the HCCI mode due to its low peak temperatures. The second one, is NO, which seems to influence the auto-ignition by very low amounts $[\mathbf{2 2 , 2 3 ]}$. Furthermore, if the ignition timing is too early, it is quite possible that NO is formed in the emission gases. The third is $\mathrm{CH}_{2} \mathrm{O}$, which is the smallest aldehyde and of which the emission is thought of being restricted by regulations in the near future. The addition of $\mathrm{CO}$ and $\mathrm{NO}$ is changed from 0 to $170 \mathrm{ppmv}$ and that of $\mathrm{CH}_{2} \mathrm{O}$ from 0 to 1400 ppmv. The chemical species, $\mathrm{CO}, \mathrm{NO}$ and formaldehyde are one of the most important minor species present in EGR that contribute to toxic pollution. Therefore, the chemistry of the auto-ignition of n-heptane, iso-octane, toluene as well as the interaction of the chemical species $\mathrm{CO}, \mathrm{NO}$ and $\mathrm{CH}_{2} \mathrm{O}$ will be discussed in the next section.

\section{The interaction of $\mathrm{CO}$, $\mathrm{NO}$ and $\mathrm{CH}_{2} \mathrm{O}$ with the fuels}

The HCCI chemistry of n-heptane, iso-octane and toluene is found in many works [1,31-35] and is discussed in previous work [30]. Nonetheless, a brief summary will be repeated that serves as a reference for the explanation of the interaction of the chemical species in EGR with the fuels. As said before, EGR generally presents three effects: a dilution effect, a thermic effect and a chemical effect. The first two effects are considered not to interfere with the reactions in the mechanisms. The third effect, however, does influence the reactions and therefore this interaction is discussed afterwards.

\subsection{Summary of the HCCI chemistry}

The HCCI chemistry process for n-heptane and iso-octane generally follows a two-stage ignition $[\mathbf{2 - 4 , 3 6 ]}$. The reaction sequence is initiated by a H-abstraction by molecular oxygen. The formed heptyl radical follows a series of additions to molecular oxygen and 
isomerizations, forming a relatively stable ketohydroperoxide via the species $\cdot \mathrm{C}_{7} \mathrm{H}_{14} \mathrm{OOH}$. Due to compression, the pressure and temperature of the gas increase until the ketohydroperoxide is no longer stable and decomposes into mainly cyclic ethers, olefins, products issued from $\beta$-scission and $\mathrm{OH}$ radicals. This causes a certain small heat release, which raises the pressure and temperature of the mixture, often defined as the cool flame [36]. For the intermediate-temperature range, no significant amount of heat is released and the - $\mathrm{C}_{7} \mathrm{H}_{14} \mathrm{OOH}$ radicals decompose rather into conjugate olefins, cyclic ethers and beta-scission than forming ketohydroperoxides $[\mathbf{3 7 , 3 8}]$. This type of reaction is responsible for a large part of the NTC behavior [37], where the system reactivity decreases with a rising temperature. During the cool flame the radicals $\mathrm{HO}_{2} \bullet$ are formed, which react with the fuel forming the relatively stable $\mathrm{H}_{2} \mathrm{O}_{2}$ [37]. When the temperature becomes high enough (higher than approximately $1000 \mathrm{~K}), \mathrm{H}_{2} \mathrm{O}_{2}$ decomposes into two hydroxyl radicals. The resulting $\mathrm{OH} \bullet$ radicals rapidly consume any fuel, and a rapid increase in temperature follows.

The chemical mechanism of iso-octane and n-heptane/iso-octane mixtures is generally the same, differing in the distribution of certain mass flows, especially the decomposition of the hydroperoxides [39]. The hydroperoxides of iso-octane $\left(\cdot \mathrm{C}_{8} \mathrm{H}_{16} \mathrm{OOH}\right)$ favour the formation of stable species, while the hydroperoxides of $n$-heptane $\left(\cdot \mathrm{C}_{7} \mathrm{H}_{14} \mathrm{OOH}\right)$ favour the formation of more reactive species. This makes the NTC for iso-octane longer and the final ignition delay takes place later.

Toluene has a different reaction path than either n-heptane or iso-octane. No cool flame is observed nor an NTC. The initiation reaction (with $\mathrm{O}_{2}$ ) as well as the consumption reaction (by $\mathrm{OH} \bullet$ ) of toluene are inhibitory (at lower temperatures) $[\mathbf{3 6 , 4 0 ]}$, which is unusual for primary consumption reactions for the fuel. The reason is that a very reactive radical $(\mathrm{OH} \bullet$ or $\mathrm{H} \bullet$ ) is replaced, in both reactions, by the unreactive benzyl radical $\mathrm{C}_{6} \mathrm{H}_{5} \mathrm{CH}_{2} \bullet$. This means that benzyl acts as a sink for $\mathrm{H}$ atoms, which slows down the oxidation process. The reaction of 
$\mathrm{HO}_{2} \bullet$ with benzyl $\left(\mathrm{C}_{6} \mathrm{H}_{5} \mathrm{CH}_{2} \bullet\right)$ to form benzaldehyde $\left(\mathrm{C}_{6} \mathrm{H}_{5} \mathrm{CHO}\right)$, is one of the primary consumption steps for benzyl [40] and thus for the whole system. Benzaldehyde follows then a series of decomposition reactions and reactions with molecular oxygen. The formed $\mathrm{HO}_{2} \bullet$ serves as a consumption radical and the formed $\mathrm{OH} \bullet$ (by the built up $\mathrm{H}_{2} \mathrm{O}_{2}$ ) consumes the fuel, marking the one-stage auto-ignition of toluene.

\subsection{Interaction of $\mathrm{CO}, \mathrm{NO}$ and $\mathrm{CH}_{2} \mathrm{O}$ with the fuels}

$\mathrm{CO}$ is formed in, among others, the following reactions [41]:

$\mathrm{RCHO}+\mathrm{X} \bullet=\mathrm{RCO} \bullet+\mathrm{XH}$

$\mathrm{RCO} \bullet+\mathrm{M}=\mathrm{R} \bullet+\mathrm{CO}+\mathrm{M}$

$\mathrm{HCO} \bullet+\mathrm{M}=\mathrm{H} \bullet+\mathrm{CO}+\mathrm{M}$

$\mathrm{HCO} \bullet+\mathrm{O} 2=\mathrm{CO}+\mathrm{HO} 2 \bullet$

These are the reactions that take place amongst the reactions that take place right after the cool flame. The $\mathrm{CO}$ interaction is then considered by the following reactions in the case of an engine [42, p. 593], forming $\mathrm{CO}_{2}$ :

$\mathrm{CO}+\mathrm{OH} \bullet=\mathrm{CO}_{2}+\mathrm{H} \bullet$

$\mathrm{H} \bullet+\mathrm{O}_{2}+\mathrm{M}=\mathrm{HO}_{2} \bullet+\mathrm{M}$

Here, an addition of $\mathrm{CO}$ will consume more $\mathrm{OH}$ radicals, replacing them by the less reactive $\mathrm{HO}_{2}$ radicals, leaving less for the consummation of the fuel, thus retarding the final ignition. Subramanian et al. [43] make two opposite observations. On one hand they observed a retarding effect, which was explained as by the preceding reactions. Subramanian et al. [43] also observed a promoting effect, explaining this by the following reaction:

$\mathrm{CO}+\mathrm{O}_{2}=\mathrm{CO}_{2}+\mathrm{O}$

Here two stable species, $\mathrm{CO}$ and $\mathrm{O}_{2}$ lead to the formation of an active radical, atomic oxygen, which increases the overall reactivity and thus decreases the final ignition delay. 
Yamada et al. [44] performed kinetic measurements in HCCI combustion using dimethyl ether (DME) for the investigation of the role of the intermediate species formaldehyde, which controls chain branching in the low temperature oxidation mechanism. They write further that a significant intermediate of DME is formaldehyde $\left(\mathrm{H}_{2} \mathrm{CO}\right)$ and when $\mathrm{H}_{2} \mathrm{CO}$ is formed, it shares $\mathrm{OH}$ consumption with the fuel through the reaction:

$\mathrm{H}_{2} \mathrm{CO}+\mathrm{OH} \rightarrow \mathrm{HCO}+\mathrm{H}_{2} \mathrm{O}$

$\mathrm{HCO}$ readily reacts with $\mathrm{O}_{2}$ to form $\mathrm{CO}$ and $\mathrm{HO}_{2}\left(\mathrm{HCO}+\mathrm{O}_{2} \rightarrow \mathrm{CO}+\mathrm{HO}_{2}\right)$. These are not sources (on the contrary, they are consumers) of $\mathrm{OH}$ at this temperature range; hence, this reaction acts as a chain termination step. This retards the final ignition.

NO has the ability to activate peroxy radicals and most importantly $\mathrm{HO}_{2}$ radicals, forming thereby especially $\mathrm{OH}$ radicals:

$\mathrm{HO}_{2}+\mathrm{NO}=\mathrm{OH}+\mathrm{NO}_{2}$

So the presence of $\mathrm{NO}$ at the beginning of a combustion cycle enhances the ignition delay by producing eventually more $\mathrm{OH}$ radicals that consume the fuel $[\mathbf{2 3 , 4 5 ]}$. However, excessive amounts of NO inhibit the oxidation at low and intermediate temperatures, because of the scavenging of $\mathrm{OH}$ radicals by the reactions $[\mathbf{1 4 , 1 9 , 2 4 ]}$ :

$\mathrm{NO}+\mathrm{OH}+[\mathrm{M}]=\mathrm{HONO}+[\mathrm{M}]$

$\mathrm{CO}$ and $\mathrm{CH}_{2} \mathrm{O}$ are already present in the Surrogate mechanism, NO not. For this purpose, a reduced NO submechanism, which is numerically validated from additions from 0 to 2000 ppmv NO [30], is added to the Surrogate mechanism. This NO submechanism, having 21 reactions and 12 species, is presented in table 3. 


\section{Experimental set-up}

For the experimental validation, an experimental set-up is used as is defined in previous work [30]. This section mentions the most important features emphasizing on the EGR installation. Table 2 shows the engine characteristics.

The experimental set-up comprises the CFR engine itself, the air inlet system and the fuel injection system. Two tanks are available on the installation: a pre-mixture tank and a stabilisation tank. The pre-mixture tank serves to mix the fuel as homogeneously as possible with the entering air. It serves also, if turned on, to mix the EGR flow (with its composants) with the fuel/air mixture. To simulate the EGR, three dispositions have been added to the experimental set-up. The first is a primary flow, containing diluting species. In this case, these are $\mathrm{N}_{2}$ and $\mathrm{CO}_{2}$. The second is a secondary flow, containing chemically reactive species. These are, in this paper $\mathrm{CO}, \mathrm{NO}$ and $\mathrm{CH}_{2} \mathrm{O}$. By controlling the quantity of each flow and mixing the diluting species with the chemically reactive species in an EGR-mixing-tank, a certain EGR composition can be chosen, in order to simulate EGR. The obtained EGR composition is then heated to the desired EGR temperature by a PID regulator, before entering the pre-mixture tank, mentioned previously. The EGR ratio is defined as the EGR flow divided by the total intake flow, that is: $\mathrm{F}_{\mathrm{EGR}} /\left(\mathrm{F}_{\mathrm{EGR}}+\mathrm{F}_{\text {air }}\right)$. The EGR flow (and the diluting species' flow) exhibits an error of $+/-2 \%$ and the EGR temperature of $+/-1{ }^{\circ} \mathrm{C}$. The concentrations of the chemical species $\left(\mathrm{CO}, \mathrm{NO}\right.$ and $\left.\mathrm{CH}_{2} \mathrm{O}\right)$ show an error of $+/-5 \%$. The air flows in this tank while the fuel is injected by a nozzle injector. The stabilisation tank serves for the stabilisation of the impulses of the flow of the intake air, caused by the motion of the engine's piston. The sensors that are connected to the installation are the temperature sensors for the cooling water (which is set to be $50{ }^{\circ} \mathrm{C}$ ), for the intake air, the EGR temperature and for the exhaust gasses. The temperature of the intake air and the greasing oil (which is set at $40{ }^{\circ} \mathrm{C}$ ) are regulated by a PID regulator. The intake temperature can be varied from $25^{\circ} \mathrm{C}$ to 
about $100{ }^{\circ} \mathrm{C}$. The temperature measurements exhibited a confidence interval of $+/-1{ }^{\circ} \mathrm{C}$. The equivalence ratio can be regulated by regulating the fuel injection amount and the air flow as to obtain the desired value by the following equation:

$$
\phi=\frac{\left(m_{\text {fuel }} / m_{\text {air }}\right)_{\text {actual }}}{\left(m_{\text {fuel }} / m_{\text {air }}\right)_{\text {stoichiometric }}}=\frac{\left(F_{\text {fuel }} / F_{\text {air }}\right)_{\text {actual }}}{\left(F_{\text {fuel }} / F_{\text {air }}\right)_{\text {stoichiometric }}}
$$

Here $\mathrm{m}$ is the mass in $\mathrm{kg}$ and $\mathrm{F}$ is the flow in $\mathrm{kg} / \mathrm{s}$. The equivalence ratio, showing a confidence interval of $+/-0,005$, can be varied in this way infinitely so to speak, but due to knocking restrictions the maximum value is about 0,4 to 0,6 , depending on the fuel and the compression ratio. The compression ratio can be varied from 4 to 16 , by changing the position of the cylinder head by turning a handle. This permits to calibrate the compression ratio as a function of a certain measurable position of the cylinder head. Since the temperature at inlet valve closing is estimated by the ideal gas law, the determination of the compression ratio goes along with a certain confidence interval, being $+/-0,5$. The fuel is composed by measuring the volumetric quantity $(+/-1 \mathrm{vol} \%)$ of each constituent of the fuel and mixing these together. So a $60 \%$ n-heptane $40 \%$ iso-octane fuel means that the quantity of n-heptane equalises, taking $\mathrm{V}$ as the volume:

$$
\frac{V_{n-h e p \text { tane }}}{V_{n-h e p t a n e}+V_{\text {iso-octane }}}
$$

The intake pressure can be regulated from the intake air flow meter. Pressure sensors are situated at different places in the installation for the measurement of the pressure of the air flow, the EGR flow as well as in the tank that is used for the stabilization of air waves caused by the motion of the engine's piston. For the measurement of the cylinder pressure, a pressure sensor is installed in the cylinder head, which is cooled by cooling water of about $20{ }^{\circ} \mathrm{C}$. The pressure measurement exhibits a standard deviation of the maximum pressure of around 0,12 $\%$ for a motored pressure, but this error can go up to about 1,5-2 \% at combustion and $3 \%$ for unstable combustion. 


\section{Experimental calibration of the $0 \mathrm{D}$ engine model}

The experimental validation has been performed by comparing the pressure, the heat release, the ignition delays and the $\mathrm{CO}_{2}$ emissions, excerpted from the surrogate model calculations with those of the experimental results that are obtained from previous work [30]. The pressure (P) is measured from the experimental set-up. The emission of $\mathrm{CO}_{2}$ is measured from exhaust gas analysis, using the technique of absorption by infra-red radiation, showing a measuring error of $2 \%$. The cool flame delay is defined as being the number of Crank Angle Degrees (CAD) from Bottom Dead Center (BDC) until the first heat release maximum and the final ignition delay as being the number of $\mathrm{CAD}$ from $\mathrm{BDC}$ until the second heat release maximum. These ignition delays are calculated, by using a $0 \mathrm{D}$ engine model, calculating the heat release. The heat release, $\mathrm{dQ}_{\text {release }} / \mathrm{d} \theta$ is calculated, using the following equation:

$$
\frac{d Q_{\text {release }}}{d \theta}=\frac{d Q_{\text {wall }}}{d \theta}+\frac{\gamma}{\gamma-1} P \frac{d V}{d \theta}+\frac{1}{\gamma-1} V \frac{d P}{d \theta}
$$

Here $\theta$ is the crank angle degree, while $\mathrm{dQ}_{\text {wall }} / \mathrm{d} \theta$ is the heat loss to the wall. The volume, $\mathrm{V}$, is determined from the engine geometry and $\gamma$ is the isentropic constant $\left(\mathrm{C}_{\mathrm{p}} / \mathrm{C}_{\mathrm{v}}\right)$. The heat loss is calculated at each point in time according to:

$$
Q_{\text {wall }}=h A\left(T-T_{\text {wall }}\right)
$$

where the temperature $\mathrm{T}$ is estimated by using the gas temperature, calculated from the ideal gas law. A is the surface of the cylinder. The wall temperature $\mathrm{T}_{\text {wall }}$ is estimated by measuring the heat lost to the cooling water. The formula for the heat transfer coefficient, $h$, is a Woschni correlation that is adjusted by Chang et al. [46] for HCCI engine applications, leaving room for different geometry applications, expressed by the scaling factor, $\alpha_{\text {scaling: }}$

$$
h_{\text {global }}=\alpha_{\text {scaling }}\left(\frac{V(\theta)}{0,25 \pi D^{2}}\right)^{-0,2} P^{0,8} T^{-0,73} w^{0,8}
$$

with 


$$
w=\left(C_{11}+C_{12} \frac{\pi D \omega_{c}}{\overline{S_{p}}}\right) \bar{S}_{p}+\frac{C_{2}}{6} \frac{V_{d} T_{i}}{P_{i} V_{i}}\left(P-P_{\text {motored }}\right)
$$

with $\omega_{\mathrm{c}}$ the angular crank shaft velocity in $\mathrm{rad} / \mathrm{s}$. Here, for the constants the next values are taken: $\mathrm{C}_{11}=2.28, \mathrm{C}_{12}=0.308$ and $\mathrm{C}_{2}=0.324 \mathrm{~cm} / \mathrm{Ks}$. Still, two entities should be estimated in order to calibrate the $0 \mathrm{D}$ engine model. The first one is the scaling factor and the second one is the wall temperature. The wall temperature is estimated, by measuring the temperature of the inlet and outlet cooling temperature. This allows to estimate the heat that is absorbed by the cooling water. Then, assuming that the heat through the cylinder wall is only transferred from conduction through the wall and convection to the cooling water and totally absorbed by the cooling water, the following equation can be written:

$$
Q_{\text {loss }}=\left(\frac{1}{\left(\frac{t}{k_{\text {c.i. }}}+\frac{1}{h_{\text {water }}}\right)}\right) A\left(T_{\text {wall }}-T_{\text {cooling }}\right)
$$

Hereby, $\mathrm{k}_{\mathrm{ci}}$ is the thermal conductivity coefficient of the cast iron cylinder wall and $\mathrm{h}_{\text {water }}$ the heat convection coefficient of the cooling water. Using a heat transfer correlation, proposed by Gnielinsky for flow across smooth circular cylinders, $\mathrm{h}_{\text {water }}$ can be estimated by the following equations:

$$
\begin{gathered}
N u_{l}=0,3+\sqrt{N u_{l, \text { lam }}^{2}+N u_{l, \text { turb }}^{2}} \\
N u_{l, \text { lam }}=0,664+\sqrt{\operatorname{Re}_{l} \sqrt[3]{\operatorname{Pr}}} \\
N u_{l, \text { turb }}=\frac{0,037 \operatorname{Re}_{l}^{0,8} \operatorname{Pr}}{1+2,443 \operatorname{Re}_{l}^{-0,1}\left(\operatorname{Pr}^{2 / 3}-1\right)}
\end{gathered}
$$

The estimation of the wall temperature exhibits an error of $+/-20 \mathrm{~K}$ for values around $400 \mathrm{~K}$. The same heat that is absorbed by the cooling water is assumed to be equal to the heat that is lost from the cylinder gases to the cylinder wall. By altering the scaling factor until the $\mathrm{Q}_{\text {wall }}$ 
equals $\mathrm{Q}_{\text {scaling, }}$ the scaling factor, $\alpha_{\text {scaling }}$ is estimated to be 505 . This value is kept constant throughout the experiments.

When comparing the calculations of the surrogate mechanism to the experimental results another problem arises, that of the effect of the residual gases, since the temperature at Inlet Valve Closing (IVC) is not equal to $\mathrm{T}_{\text {inlet. }}$ Lacking means to measure this effect, an estimation is done, which is based on the calculation of the residual gas fraction and temperature. Using an enthalpie balance and the following equations, the residual gas fraction and temperature are estimated by means of iteration:

$$
\begin{aligned}
& f=\frac{T_{\text {inlet }}}{\left(\frac{P_{I V C} r_{E}}{P_{E} r_{I V C}} \varepsilon-\frac{C_{p, R}}{C_{p, I V C}}\left(\frac{P_{I V C}}{P_{E}}\right)^{\left(\frac{\bar{T}-1}{\bar{T}}\right)}\right) T_{E}+\left(\frac{C_{p, R}}{C_{p, I V C}}-1\right) T_{0}+T_{\text {inlet }}} \\
& T_{I V C}=\frac{P_{I V C} r_{E}}{P_{E} r_{I V C}} f \varepsilon T_{E}
\end{aligned}
$$

Here, $r$ is the mass ideal gas constant, $\mathrm{T}_{\mathrm{E}}$ and $\mathrm{P}_{\mathrm{E}}$, respectivley the measured exhaust temperature and pressure, $\mathrm{T}_{0}$, the reference temperature, $298 \mathrm{~K}$ and $\bar{T}=\sqrt{T_{E} T_{R}}$, the mean temperature. This method allows estimating the residual gas temperature and fraction with a deviation of $+/-25-30 \mathrm{~K}$ for the residual gas temperature and $10-15 \%$ for the residual gas fraction, depending on the equivalence ratio and the compression ratio. The subsequent error in the temperature at IVC, the temperature that should be put as an input parameter for simulations, is then $5-8{ }^{\circ} \mathrm{C}$. This shows that the impact of the residual gas is crucial and it could well be the main factor of error in comparing the experimental results with the chemical kinetic calculations of the surrogate mechanism. 


\section{Experimental validation of the surrogate mechanism}

In this section, the surrogate mechanism is compared to the experimental results with respect to the EGR parameters. The fuels that are used in this experimental validation study are nheptane and PRF40 ("60 vol\% n-heptane/40 vol\% iso-octane). The influence of the dilution and the EGR temperature should not be dependent on the fuel used. The chemical species CO interacts with primarily $\mathrm{OH}$ radicals and oxygen, according to section 2 of this paper. Also, the species $\mathrm{NO}$ interacts with the $\mathrm{OH}$ radicals and with $\mathrm{HO}_{2}$ radicals, while the species $\mathrm{CH}_{2} \mathrm{O}$ primarily interacts with the $\mathrm{OH}$ radicals. Since the $\mathrm{OH}$ and $\mathrm{HO}_{2}$ radicals and molecular oxygen are present in the auto-ignition reaction paths of each investigated fuel, the type of influence should be the same for each fuel. This makes the study of the influence of species as $\mathrm{CO}, \mathrm{NO}$ and $\mathrm{CH}_{2} \mathrm{O}$ general and applicable to many other fuels. The difference lies in the degree of influence, since the amount of $\mathrm{OH}$ radicals or $\mathrm{HO}_{2}$ radicals formed, depend on the fuel. Nonetheless, this does not prevent the extrapolation of the influence of such species on the auto-ignition process to other fuels. The use of other fuels for the auto-ignition process is discussed in former work [30] and is not the issue of this paper. For this, it is ought to be enough to use the fuels n-heptane and PRF40, being the fuels that are mostly used for autoignition purposes [6-10].

For the experimental validation, the same accuracy criterions are used as for the numerical validation in previous work [30]. Since experimental validation already has to deal with measuring errors, the accuracy levels are larger than for the numerical validation. For the level accuracy, $1 \mathrm{CAD}$ was taken for the ignition delays. The previous section has estimated a numerical ignition delay error of 0,5 CAD. Therefore, the comparison of the modeling results (Mechanism) and the experimental results (Experiment) are considered within the level of accuracy, when the error is less than 1,5 CAD. The accurcy intervals for the other entities are taken on the same basis, being 1,5 bar for the maximum pressure, $15 \%$ for the maximum heat 
release and $15 \%$ for the $\mathrm{CO}_{2}$ emissions. For the experimental validation, the dilution by $\mathrm{N}_{2}$ or by $\mathrm{CO}_{2}$ is taken from 0 to $46 \mathrm{vol} \%$. The EGR temperature is changed from 30 to $120^{\circ} \mathrm{C}$. The addition of $\mathrm{CO}$ and $\mathrm{NO}$ is altered from 0 to $170 \mathrm{ppmv}$, while the addition of $\mathrm{CH}_{2} \mathrm{O}$ is varied between 0 and 1400 ppmv. Concerning the comparison for the $\mathrm{CO}_{2}$ emission, only some interesting examples will be shown.

\subsection{Comparison of the surrogate mechanism and the experimental results, varying the dilution and thermal aspect of EGR}

Figure 1 shows the comparison between the auto-ignition delays for experiments with nheptane and those predicted by the surrogate mechanism, varying the dilution by $\mathrm{N}_{2}$ for two equivalence ratios. Figure 2 shows the same comparison, but for the fuel PRF40. Figure 3 shows the same as figure 2 , but the dilution is now by $\mathrm{CO}_{2}$, having a higher heat capacity. Figure 4 shows a comparison between the pressure and heat release issued from the experiments and those issued from the kinetic surrogate mechanism. The comparison between the experimental results and the modeling results is of satisfactory quality, for different heat capacities, represented by $\mathrm{N}_{2}$ and $\mathrm{CO}_{2}$. The ignition delays, pressure and heat release seem to show a good agreement. However, at higher dilution factors of $\mathrm{N}_{2}$ and $\mathrm{CO}_{2}$, it seems that the ignition delays show less good agreement. Apparently, the engine model does not operate well at relatively higher dilution factors, since this engine model is not designed for that purpose. The difference in the heat capacities between the burned gases and the dilution species, for instance, becomes more and more difficult to simulate by the engine model as the dilution factor increases. This has its impact on the estimation of the residual gas temperature and thus on the modelling initial conditions. The discrepancy at higher dilutions is higher for the PRF40 than for n-heptane. This suggests, since n-heptane auto-ignites more easily, that at

a dilution of $46 \mathrm{vol} \%$ the combustion is made too difficult for PRF40 to take place 
completely, having therefore incomplete combustion. Figure 5 seems to confirm this, showing much less $\mathrm{CO}_{2}$ formed from the experiments at a dilution of $46 \mathrm{vol} \%$ than predicted by the mechanism. This discrepancy is even more clearly visible for an equivalence ratio of 0,32 than 0,40 . Figure 6 shows the comparison of the Surrogate mechanism and the experimental results, with respect to the EGR temperature. The comparison for the EGR temperature shows no disagreement, which is expected, since it represents the same comparison as is done for the inlet temperature. So, further analysis is not necessary. Nevertheless, it is worth noting that in reality the dilution by EGR entames differences in the heat capacity. The heat capacity of the burned gases will generally be higher than that of the fresh air that enters the cylinder. Therefore, the effect of the EGR temperature will be relatively higher than that of the inlet temperature. However, if the range of the EGR temperature is slightly higher, if not the same, and the volumetric flow is lower, the effect of the EGR temperature would be lower than that of the inlet temperature. These two effect can cancel each other out or one can prevail above the other, depending on the experimental conditions. In the case of this work, the inlet temperature seemed to have a higher influence than the EGR temperature and therefore any discrepancy of the modelling results with the experimental results would be less observed for the EGR temperature than for the inlet temperature.

\subsection{Comparison of the surrogate mechanism and the experimental results, varying the chemical aspect of EGR}

This section treats the influence of some chemical species on the auto-ignition process, that are present in EGR. Figure 7 shows the influence of $\mathrm{CO}$ on the auto-ignition delays, for the fuel n-heptane. For the fuel PRF40 no influence is observed either. As concerns the addition of $\mathrm{CO}$, no discrepancy is found, since both the surrogate mechanism and the experimental results did not show any influence of $\mathrm{CO}$ on the auto-ignition process at the investigated 
ranges. Figure 8 shows the influence of NO on the auto-ignition delays for the fuel PRF40. The added reduced NO sub mechanism, showed qualitatively satisfactory agreement between the mechanism and the experiments. However, quantitatively, this comparison was not that well. This discrepancy is probably due to the fact that the NO sub mechanism was validated in constant volume environments at other conditions. In an engine the pressure and temperature profiles are intrinsically different than that in a constant volume reactor, for instance. This could have an impact on the kinetics of a kinetic mechanism. More investigation is needed to clarify the influence of different physical properties of experimental apparati on the kinetics of the oxidation of a species. The last chemical species to be shown, is formaldehyde. Figure 9 shows the influence of formaldehyde on the auto-ignition delays for the fuel PRF40. The influence of formaldehyde on the ignition delays is well reproduced by the surrogate mechanism for two different equivalence ratios over the whole range of added $\mathrm{CH}_{2} \mathrm{O}$.

\subsection{Domain of validity for the reduced kinetic mechanism "Surrogate"}

Respecting the criteria mentioned at the beginning of section 5 , table 4 shows a summary of the domain of validity (issued from a series of experiments and calculations of which some important examples are shown in this paper) for the dilution by $\mathrm{N}_{2}$, by $\mathrm{CO}_{2}$, the EGR temperature as well as the addition of $\mathrm{CO}, \mathrm{NO}$ and $\mathrm{CH}_{2} \mathrm{O}$. Table 4 shows that for the EGR temperature, the addition of $\mathrm{CO}$ and the addition of $\mathrm{CH}_{2} \mathrm{O}$, the mechanism is validated within the whole range that is investigated, though is should be mentioned that no influence of $\mathrm{CO}$ on the auto-ignition is observed in the investigated range. As for the dilution by $\mathrm{N}_{2}$, the mechanism is validated between a dilution of 0 and $30 \mathrm{vol} \%$, whilst for $\mathrm{CO}_{2}$ the range is between 0 and $25 \mathrm{vol} \%$. As for NO, the domain of validity is found to be qualitative over the whole range investigated. However, in quantitatively the validity of the mechanism is found to be between 0 and 25 and between 80 and 170 ppmv. In other words, it seems that between 
25 and 80 ppmv, the NO submechanism underestimates the influence of NO, but predicts the trend rather satisfactorily.

\section{Conclusions}

In former work, a surrogate mechanism is composed out of 62 reactions and 49 species, representing the auto-ignition of mixtures of n-heptane, iso-octane and toluene and validated numerically. In this paper, this surrogate mechanism is validated experimentally in a wide range of parameters respecting HCCI initial conditions. The parameters involved dilution, thermal and chemical effects present in EGR. The validation is satisfactory for a dilution by $\mathrm{N}_{2}$ from 0 to $30 \mathrm{vol} \%$, while the validity range is 0 to $21 \mathrm{vol} \%$ in the case of dilution by $\mathrm{CO}_{2}$. The thermal part is represented by the EGR temperature, validating the surrogate mechanism from an EGR temperature of 30 to $120{ }^{\circ} \mathrm{C}$. As far as it concerns the chemical species, additions of 0 to $170 \mathrm{ppmv}$ for $\mathrm{CO}$ caused no discrepancy between the surrogate mechanism and the experimental results. The same is the case for the addition of formaldehyde between 0 and 1400 ppmv. The influence of NO on the auto-ignition process is quantitatively well predicted by the surrogate mechanism with an addition of 0 to 25 and 80 to 170 ppmv. For the influence of $\mathrm{NO}, \mathrm{a} \mathrm{NO}_{\mathrm{x}}$ submechanism was added to the surrogate mechanism. The validity was observed to be qualitatively acceptable over the whole range of NO addition. The behaviour of the auto-ignition process, influenced by the EGR parameters, especially the chemical ones, appeared to be generally well predicted by the surrogate mechanism. It can be said that this Surrogate mechanism is representative for describing the auto-ignition of mixtures of n-heptane, iso-octane and toluene, being generally accepted as surrogates to real fuels. A future application could be the implementation of the surrogate mechanism in a realistic engine code and simulation of the interaction of real EGR with the auto-ignition process of real fuels. 


\section{References}

[1] Huang Y, Sung CJ, Eng JA. Dilution limits of n-butane/air mixtures under conditions relevant to HCCI combustion. Comb. Flame 2004; 136: 457-466.

[2] Curran HJ, Gaffuri P, Pitz WJ, Westbrook CK. A comprehensive Modeling Study of isoOctane Oxidation. Comb. Flame 2002; 129: 253-280.

[3] Tanaka S, Ayala F, Keck JC. A reduced chemical kinetic model for HCCI combustion of primary reference fuels in a rapid compression machine. Comb. Flame 2003; 133: 467-481.

[4] Tanaka S, Ayala F, Keck JC, Heywood JB. Two-stage ignition in HCCI combustion and HCCI control by fuels and additives. Comb. Flame 2003; 132: 219-239.

[5] Griffiths JF, MacNamara JP, Sheppard CGW, Turton DA, Whitaker BJ. The relationship of knock during controlled autoignition to temperature inhomogeneities and fuel reactivity. Fuel 2002; 81: 2219-2225.

[6] Bikas G, Peters N. Brief communication: Kinetic Modelling of n-Decane Combustion and Autoignition. Comb. Flame 2001; 126: 1456-1475.

[7] Aichlmayr HT, Kittelson DB, Zachariah MR. Miniature free-piston homogeneous charge compression ignition engine-compressor concept - Part II: modeling HCCI combustion in small scales with detailed homogeneous gas phase chemical kinetics. Chem. Eng. Sc. 2002; 57: 4173-4186.

[8] Ogink R, Golovitchev V. Generalised Skeletal Reaction Mechanism For Aliphatic Hydrocarbons (From Methane To Iso-octane) For CFD Engine Modelling. First Biennial Meeting of The Scandinavian-Nordic Section of the Combustion Institute, Göteborg 2001: 151-156.

[9] Gauthier BM, Davidson DF, Hanson RK. Shock tube determination of ignition delay times in full-blend and surrogate fuel mixtures. Comb. Flame 2004; 139: 300-311. 
[10] Minetti R, Carlier M, Ribaucour M, Therssen E, Sochet LR. Comparison of oxidation and autoignition of the two primary reference fuels by rapid compression. Twenty-Sixth Symposium (International) on Combustion 1996: 747-753.

[11] Sung CJ, Huang Y, Eng JA. Effects of Reformer Gas Addition on the Laminar Flame Speeds and Flammability Limits of n-Butane and iso-Butane Flames. Comb. Flame 2001; 126: $1699-1713$.

[12] Mitchell DL, Pinson JA, Litzinger TA. The effects of simulated EGR via intake air dilution on combustion in an optically accessible DI diesel engine, 1993. SAE International, Fuels \& Lubricants Meeting \& Exhibition, SAE-932798.

[13] Li J, Chae JO, Park SB, Paik HJ, Park JK, Jeong YS, Lee SM, Choi YJ. Effect of intake composition on combustion and emission characteristics of DI diesel engine at high intake pressure, 1997. SAE International, International Congress \& Exposition, SAE-970322.

[14] Ladommatos N, Abdelhalim SM, Zhao H, Hu Z. The dilution, chemical, and thermal effects of exhaust gas recirculation on diesel engine emissions - Part 1: effect of reducing inlet charge oxygen, 1996. SAE International, International Spring Fuels and Lubricants Meeting, SAE-961165.

[15] Babajimopoulos A, Lavoie GA, Assanis DA. Modeling HCCI combustion with high levels of residual gas fraction - A comparison of two VVA strategies, 2003. SAE 2003-013220.

[16] Gauthier BM, Davidson DF, Hanson RK. Shock tube determination of ignition delay times in full-blend and surrogate fuel mixtures. Comb. Flame 2004; 139: 300-311.

[17] Chen R, Milovanovic N. A computational study into effect of exhaust gas recycling on homogeneous charge compression ignition combustion in internal combustion engines fuelled with methane. Intern. J. Therm. Sc. 2002; 41: 805-813. 
[18] Zhao H, Peng Z, Williams J, Ladommatos N. Understanding the effects of recycled burnt gases on the controlled autoignition (CAI) combustion in four-stroke engines, 2001. SAE International, International Fall Fuels and Lubricants Meeting and Exposition, 2001-01-3607. [19] Ladommatos $\mathrm{N}$, Abdelhalim SM, Zhao H, Hu Z. The dilution, chemical, and thermal effects of exhaust gas recirculation on diesel engine emissions - Part 2: effects of carbon dioxide, 1996. SAE International, International Spring Fuels and Lubricants Meeting, SAE961167.

[20] Ladommatos $\mathrm{N}$, Abdelhalim SM, Zhao H, Hu Z. The dilution, chemical, and thermal effects of exhaust gas recirculation on diesel engine emissions - Part 3: effects of water vapour, 1997. SAE International, International Spring Fuels and Lubricants Meeting, SAE971659.

[21] Kumar MS, Ramesh A, Nagalingam B. Use of hydrogen to enhance the performance of a vegetable oil fuelled compression ignition engine. Intern. J. Hydr. Ener. 2002; 28: 1143-1154. [22] Pinard PF, Higgins AJ, Lee JHS. The effects of $\mathrm{NO}_{2}$ addition on deflagration-todetonation transition. Comb. Flame 2003; 136: 146-154.

[23] Faravelli T, Frassoldati A, Ranzi E. Kinetic modeling of the interactions between NO and hydrocarbons in the oxidation of hydrocarbons at low temperatures. Comb. Flame 2003; 132: 188-207.

[24] Ladommatos N, Abdelhalim SM, Zhao H, Hu Z. The dilution, chemical, and thermal effects of exhaust gas recirculation on diesel engine emissions - Part 4: effects of carbon dioxide and water vapour, 1997. SAE International, International Spring Fuels and Lubricants Meeting, SAE-971660.

[25] Furutani M, Kono M, Kojima M, Nose M, Ohta Y. Chemcal species histories up to ignition in premixed-compression-ignition natural-gas engine, The fifth International 
Symposium on Diagnostics and Modeling of Combustion in Internal Combustion Engines, Comodia 2001, p. 461-466.

[26] Lovas T, Nilsson D, Mauss F. Automatic reduction procedure for chemical mechanisms applied to premixed methane/air flames, Twenty-Eighth International Symposium on Combustion, 2000: 1809-1815.

[27] Lu T, Ju Y, Law CK. Complex CSP for Chemistry Reduction and Analysis. Comb. Flame 2001; 126: 1445-1455.

[28] Maass U, Pope SB. Simplifying chemical kinetics: Intrinsic low-dimensional manifolds in composition space. Comb. Flame 1992; 88: 239-264.

[29] Warnatz J, Maass U, Dibble RW. Combustion Physical and chemical fundamentals, modeling and simulation, experiments, pollutant formation. Springer-Verlag, New York, 2000.

[30] Machrafi H. Development and experimental validation of kinetic schemes for hydrocarbon mixtures for HCCI applications. Investigation of the auto-ignition process and the application to internal combustion engines, $P h D$ thesis, University of Paris 6 (UPMC), Paris, 2007.

[31] Cox RA, Cole JA. Chemical aspects of the autoignition of hydrocarbon-air mixtures. Comb. Flame 1985; 60: 109-123.

[32] Benson SW. The kinetics and thermochemistry of chemical oxidation with application to combustion and flames. Progr. Ener. Comb. Sc. 1981; 7: 125-134.

[33] Westbrook C, Warnatz J, Pitz W. A Detailed Chemical Kinetic Reaction Mechanism for the Oxidation of Iso-Octane and n-Heptane over an Extended Temperature Range and its Application to Analysis of Engine Knock, Symposium (International) on Combustion 1988; 22: 893-901. 
[34] Blin-Simiand N, Jorand F, Keller K, Fiderer M, Sahetchian K. Ketohydroperoxides and Ignition Delay in Internal Combustion Engines. Comb. Flame 1998; 112: 278-282.

[35] Dixon-Lewis G. Computer modeling of combustion reactions in flowing systems with transport: combustion chemistry. In: J. William and C. Gardner. Springer-Verlag, New York, 1984.

[36] Glassman I. Combustion. Academic Press, San Diego, 1996. p. 84.

[37] Curran HJ, Gaffuri P, Pitz WJ, Westbrook CK. A Comprehensive Modeling Study of nHeptane Oxidation. Comb. Flame 1998; 114: 149-177.

[38] Ranzi E, Gaffuri P, Faravelli T, Dagaut P. A Wide-Range Modeling Study of n-Heptane Oxidation. Comb. Flame 1995; 103: 91-106.

[39] Dagaut $\mathrm{P}$, Reuillon $\mathrm{M}$, Cathonnet $\mathrm{M}$. High pressure oxidation of liquid fuels from low to high temperatures. 2. Mixtures of n-heptane and iso-octane. Com. Sc. Tech. 1994; 95: 233260.

[40] Emdee J, Brezinsky K, Glassman I. A Kinetic Model for the Oxidation of Toluene near 1200 K. J. Phys. Chem. 1992; 96: 2151-2161.

[41] Bowman CT. Kinetics of Pollutant Formation and Destruction in Combustion. Prog. Ener. Comb. Sc. 1975; 1: 33-45.

[42] Heywood JB. Fundamentals of Internal combustion. New York: McGrawHill; 1988.

[43] Subramanian G, Pires Da Cruz A, Vervisch L, Bonaceur R. Impact of $\mathrm{CO}$ and $\mathrm{H}_{2}$ addition on the auto-ignition delay of mixtures dedicated to Homogeneous Charge Compression Ignition (HCCI) Engines, Proceedings of the European Combustion Meeting (2005).

[44] Yamada H, Suzaki K, Sakanashi H, Choi N, Tezaki A. Kinetic measurements in homogeneous charge compression of dimethyl ether: role of intermediate formaldehyde 
controlling chain branching in the low-temperature oxidation mechanism. Comb. Flame 2005; 140: 24-33.

[45] Frassoldati A, Faravelli T, Ranzi E. Kinetic modeling of the interactions between NO and hydrocarbons at high temperature. Comb. Flame 2003; 135: 97-112.

[46] Chang J, Güralp O, Filipi Z, Assanis D, Kuo TW, Najt P, Rask R. New Heat Transfer Correlation for an HCCI Engine Derived from Measurements of Instantaneous Heat Flux, 2004. SAE 2004-01-2996. 


\section{Figure captions}

Figure 1: Comparison between modelling ignition delays and experimental ignition delays at an inlet temperature of $70{ }^{\circ} \mathrm{C}$, an equivalence ratio of 0,32 and 0,4 , a compression ratio of $10,2, \mathrm{n}$-heptane as the fuel, varying the $\mathrm{N}_{2}$ percentage in the inlet mixture

Figure 2: Comparison between modelling ignition delays and experimental ignition delays at an inlet temperature of $70{ }^{\circ} \mathrm{C}$, an equivalence ratio of 0,32 and 0,4 , a compression ratio of 10,2 , "60 vol\% n-heptane / 40 vol\% iso-octane" as the fuel, varying the $\mathrm{N}_{2}$ percentage in the inlet mixture

Figure 3: Comparison between modelling ignition delays and experimental ignition delays at an inlet temperature of $70^{\circ} \mathrm{C}$, an equivalence ratio of 0,321 and 0,389 , a compression ratio of 10,2, " 60 vol $\%$ n-heptane / 40 vol\% iso-octane" as the fuel, varying the $\mathrm{CO}_{2}$ percentage in the inlet mixture

Figure 4: Comparison between modelling and experimental pressure and heat release at an inlet temperature of $70{ }^{\circ} \mathrm{C}$, an equivalence ratio of 0,4 , a compression ratio of $10,2, " 60 \mathrm{vol} \%$ n-heptane / 40 vol\% iso-octane", with an $\mathrm{N}_{2}$ dilution of 23 vol\%

Figure 5: Comparison of the experimental and modelling $\mathrm{CO}_{2}$ emission as a function of the dilution by $\mathrm{N}_{2}$, at an equivalence ratio of 0,32 and 0,41 , a compression ratio of 10,2 , an inlet temperature of $70{ }^{\circ} \mathrm{C}$ and the fuel " 60 vol\% n-heptane / 40 vol\% iso-octane"

Figure 6: Comparison between modelling ignition delays and experimental ignition delays at an inlet temperature of $70{ }^{\circ} \mathrm{C}$, an equivalence ratio of 0,389 , a compression ratio of 10,2, " 60 vol\% n-heptane / 40 vol\% iso-octane" as the fuel, varying the EGR temperature by a dilution of $23 \mathrm{vol} \% \mathrm{~N}_{2}$

Figure 7: Comparison between modelling ignition delays and experimental ignition delays at an inlet temperature of $70{ }^{\circ} \mathrm{C}$, an equivalence ratio of 0,35 , a compression ratio of $10,2, \mathrm{n}$ heptane as the fuel, varying the addition of $\mathrm{CO}$ 
Figure 8: Comparison between modelling ignition delays and experimental ignition delays at an inlet temperature of $70{ }^{\circ} \mathrm{C}$, an equivalence ratio of 0,33 , a compression ratio of 10,2, " 60 vol $\%$ n-heptane / 40 vol $\%$ iso-octane" as the fuel, varying the addition of NO

Figure 9: Comparison between modelling ignition delays and experimental ignition delays at an inlet temperature of $70{ }^{\circ} \mathrm{C}$, an equivalence ratio of 0,32 and 0,41 , a compression ratio of 10,2, " 60 vol\% n-heptane / 40 vol\% iso-octane" as the fuel, varying the $\mathrm{CH}_{2} \mathrm{O}$ content in the inlet mixture 


\section{Figures}

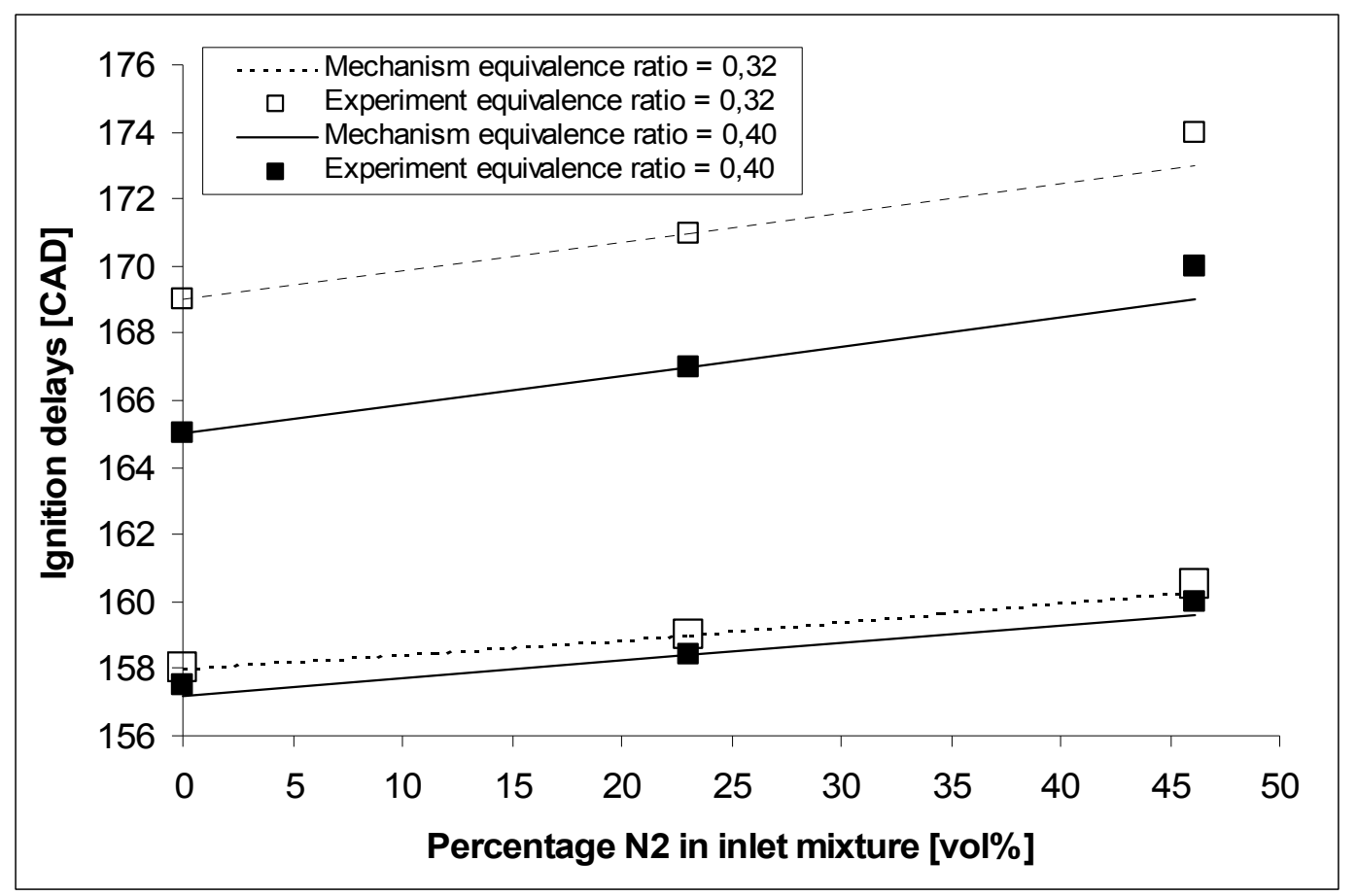

Figure 1: Comparison between modelling ignition delays and experimental ignition delays at an inlet temperature of $70{ }^{\circ} \mathrm{C}$, an equivalence ratio of 0,32 and 0,4 , a compression ratio of $10,2, \mathrm{n}$-heptane as the fuel, varying the $\mathrm{N}_{2}$ percentage in the inlet mixture 


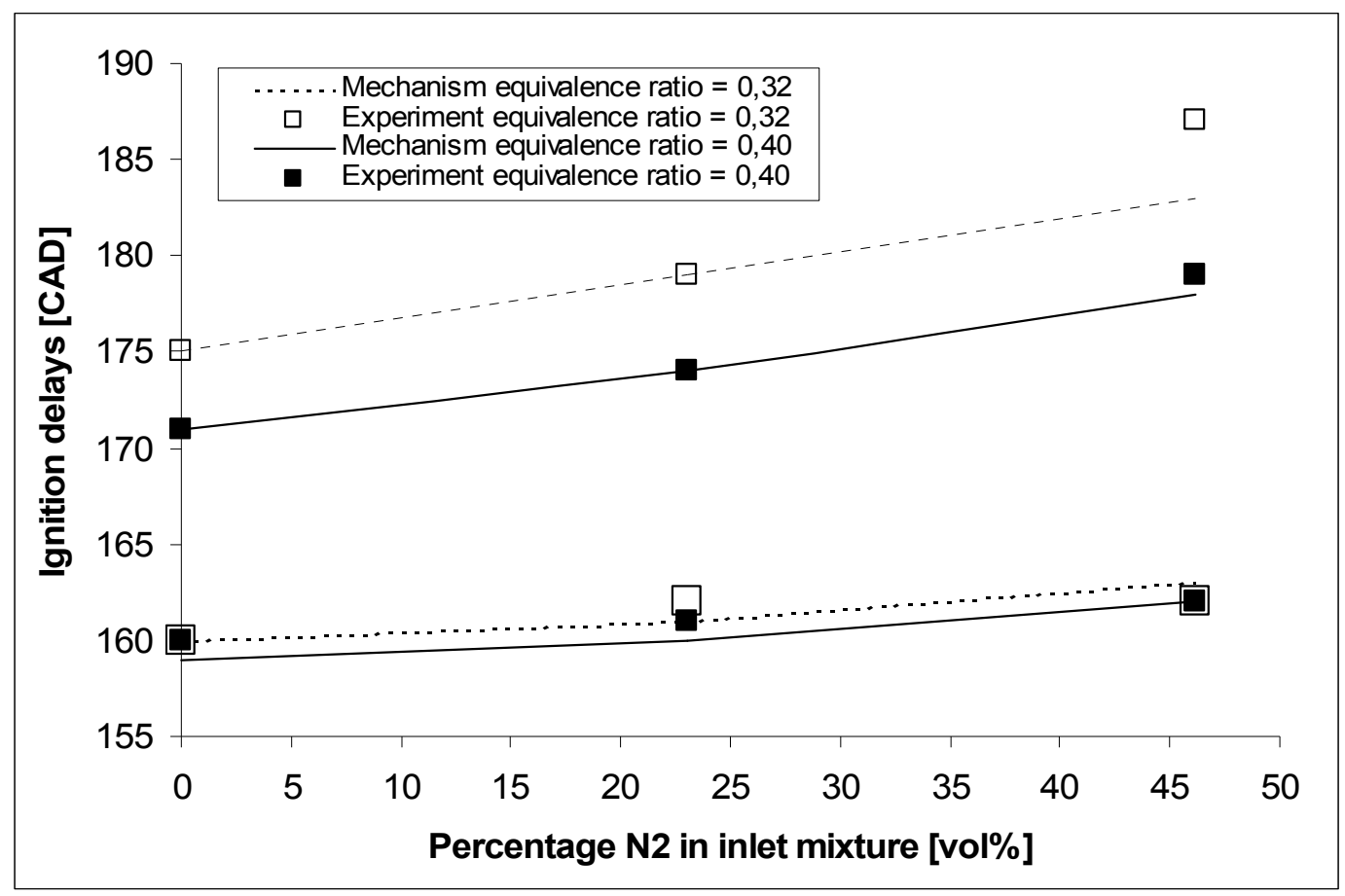

Figure 2: Comparison between modelling ignition delays and experimental ignition delays at an inlet temperature of $70{ }^{\circ} \mathrm{C}$, an equivalence ratio of 0,32 and 0,4 , a compression ratio of 10,2, " $60 \mathrm{vol} \% \mathrm{n}$-heptane / $40 \mathrm{vol} \%$ iso-octane" as the fuel, varying the $\mathrm{N}_{2}$ percentage in the inlet mixture 


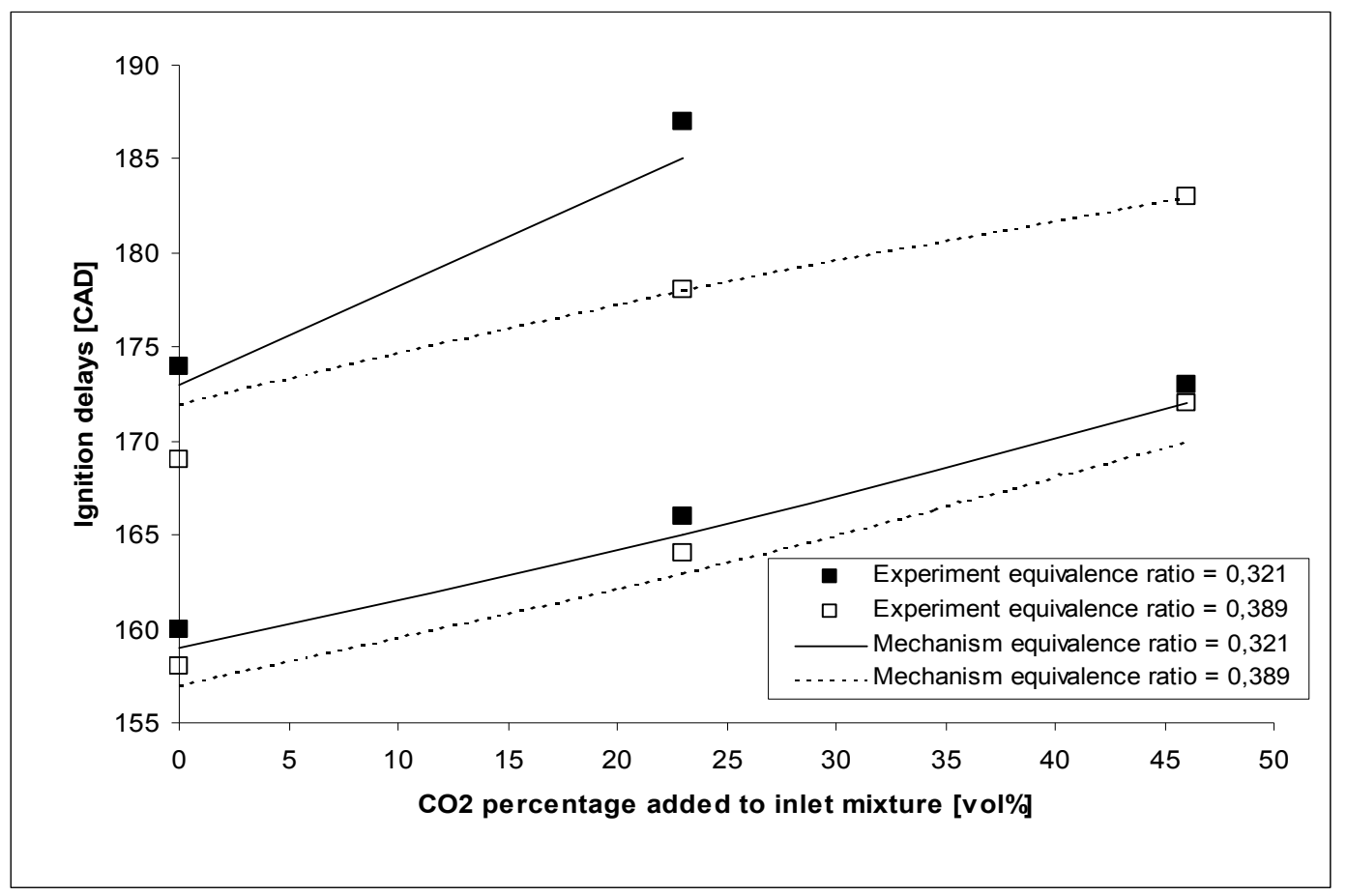

Figure 3: Comparison between modelling ignition delays and experimental ignition delays at an inlet temperature of $70^{\circ} \mathrm{C}$, an equivalence ratio of 0,321 and 0,389 , a compression ratio of 10,2, " 60 vol\% n-heptane / 40 vol\% iso-octane" as the fuel, varying the $\mathrm{CO}_{2}$ percentage in the inlet mixture 


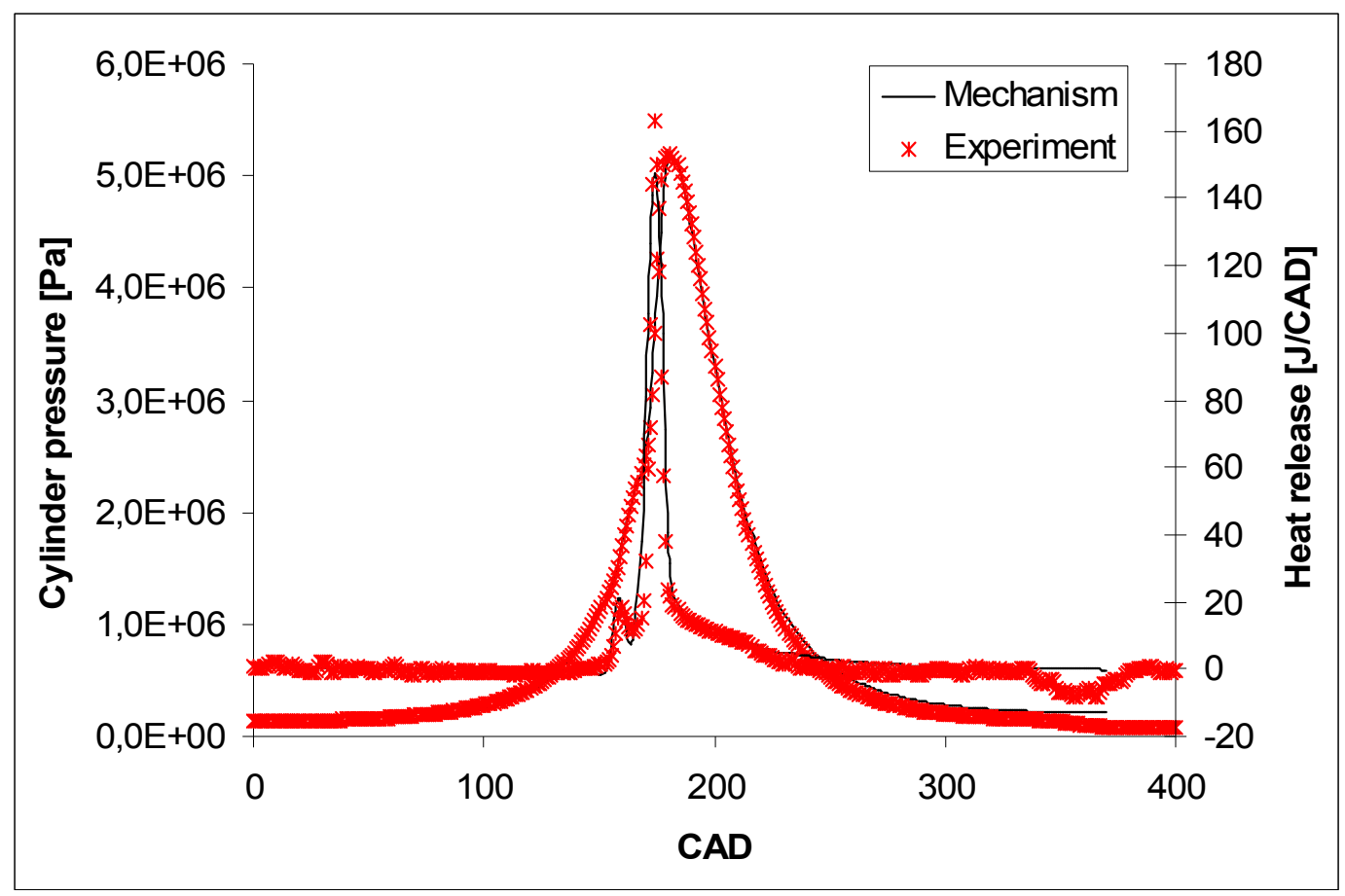

Figure 4: Comparison between modelling and experimental pressure and heat release at an inlet temperature of $70{ }^{\circ} \mathrm{C}$, an equivalence ratio of 0,4 , a compression ratio of 10,2, " 60 vol\% n-heptane / 40 vol\% iso-octane", with an $\mathrm{N}_{2}$ dilution of $23 \mathrm{vol} \%$ 


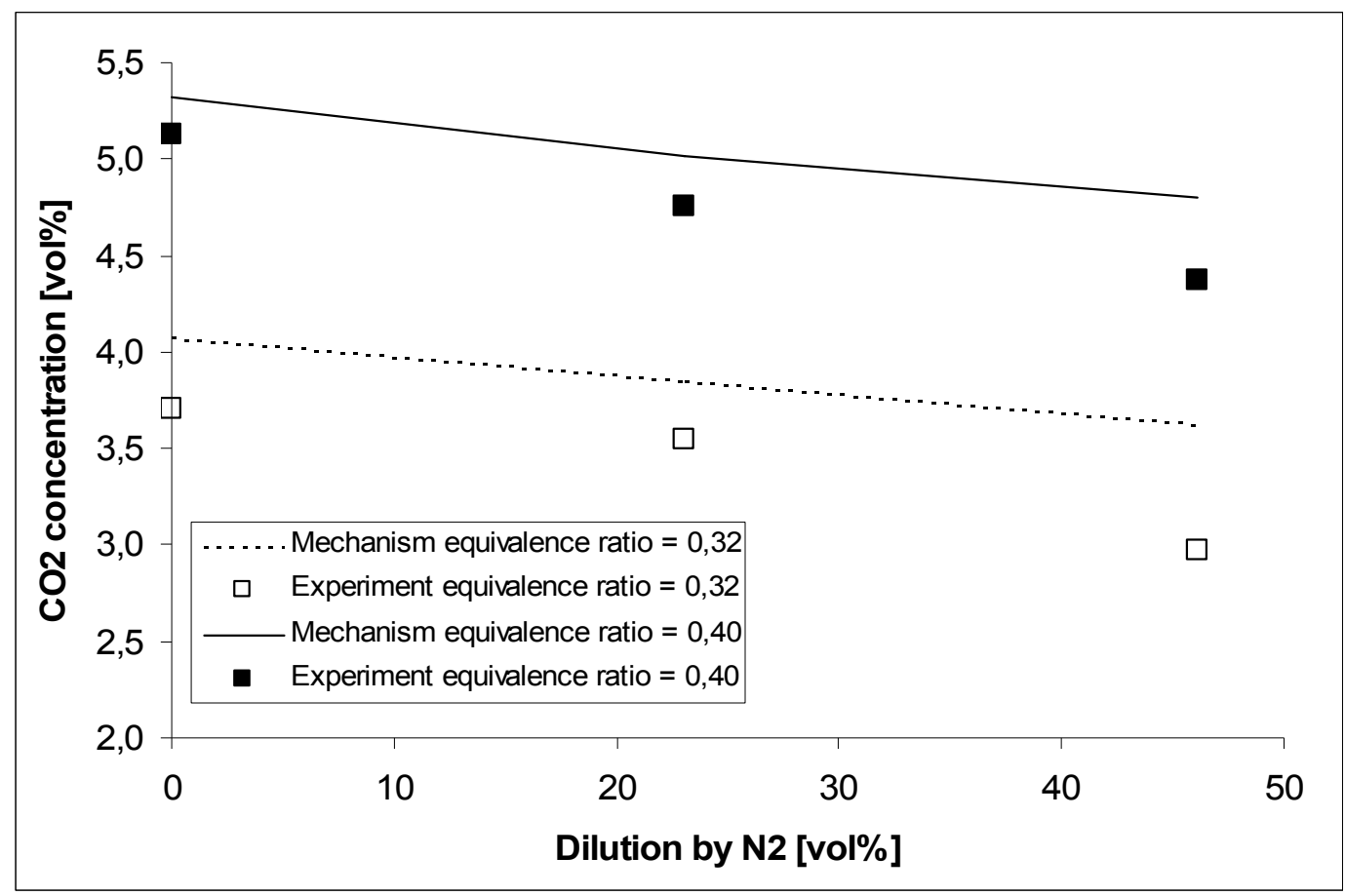

Figure 5: Comparison of the experimental and modelling $\mathrm{CO}_{2}$ emission as a function of the dilution by $\mathrm{N}_{2}$, at an equivalence ratio of 0,32 and 0,41 , a compression ratio of 10,2 , an inlet temperature of $70{ }^{\circ} \mathrm{C}$ and the fuel " 60 vol\% n-heptane / 40 vol\% iso-octane" 


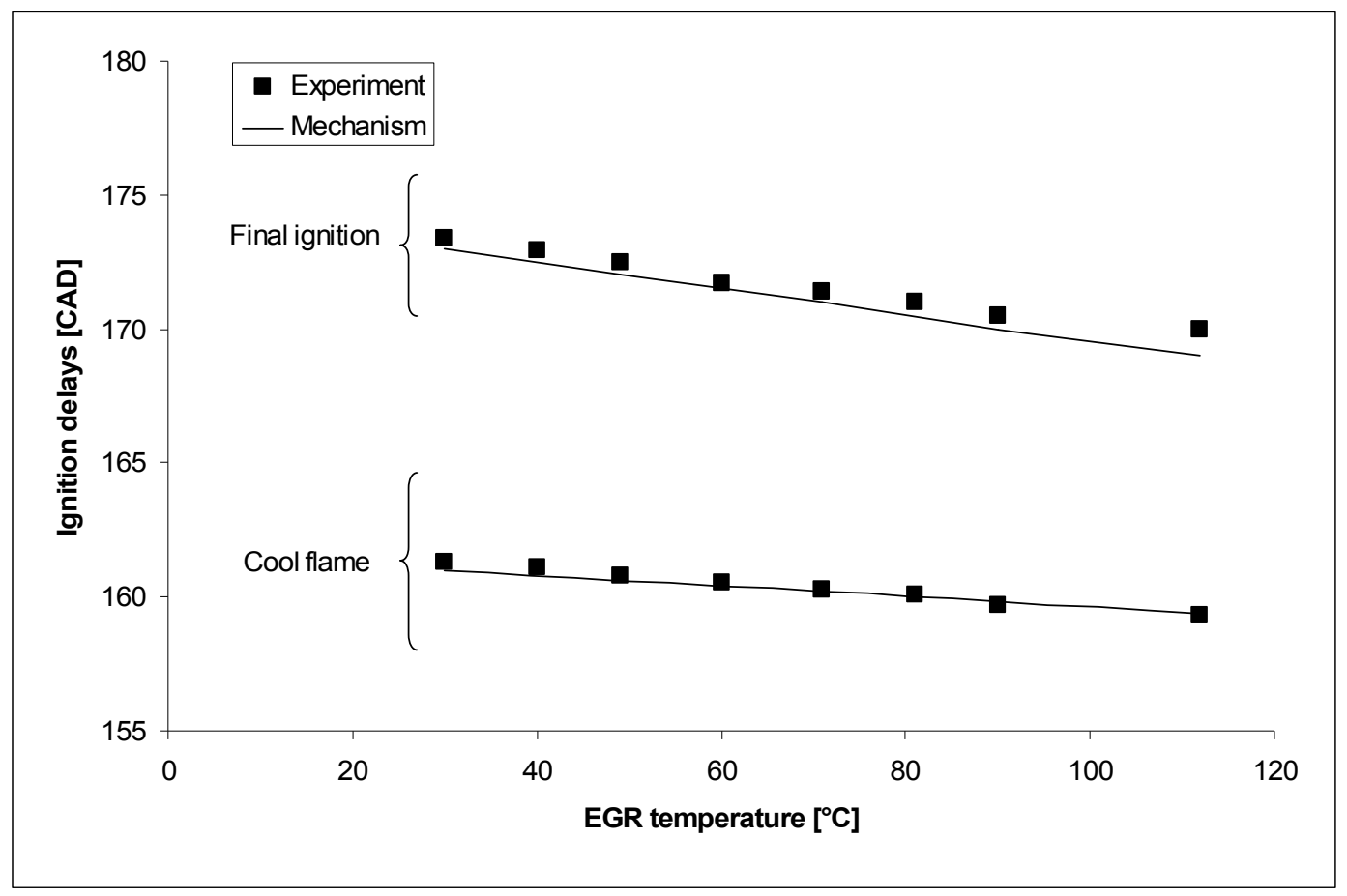

Figure 6: Comparison between modelling ignition delays and experimental ignition delays at an inlet temperature of $70{ }^{\circ} \mathrm{C}$, an equivalence ratio of 0,389 , a compression ratio of $10,2, " 60$ vol\% n-heptane / 40 vol\% iso-octane" as the fuel, varying the EGR temperature by a dilution of $23 \mathrm{vol} \% \mathrm{~N}_{2}$ 


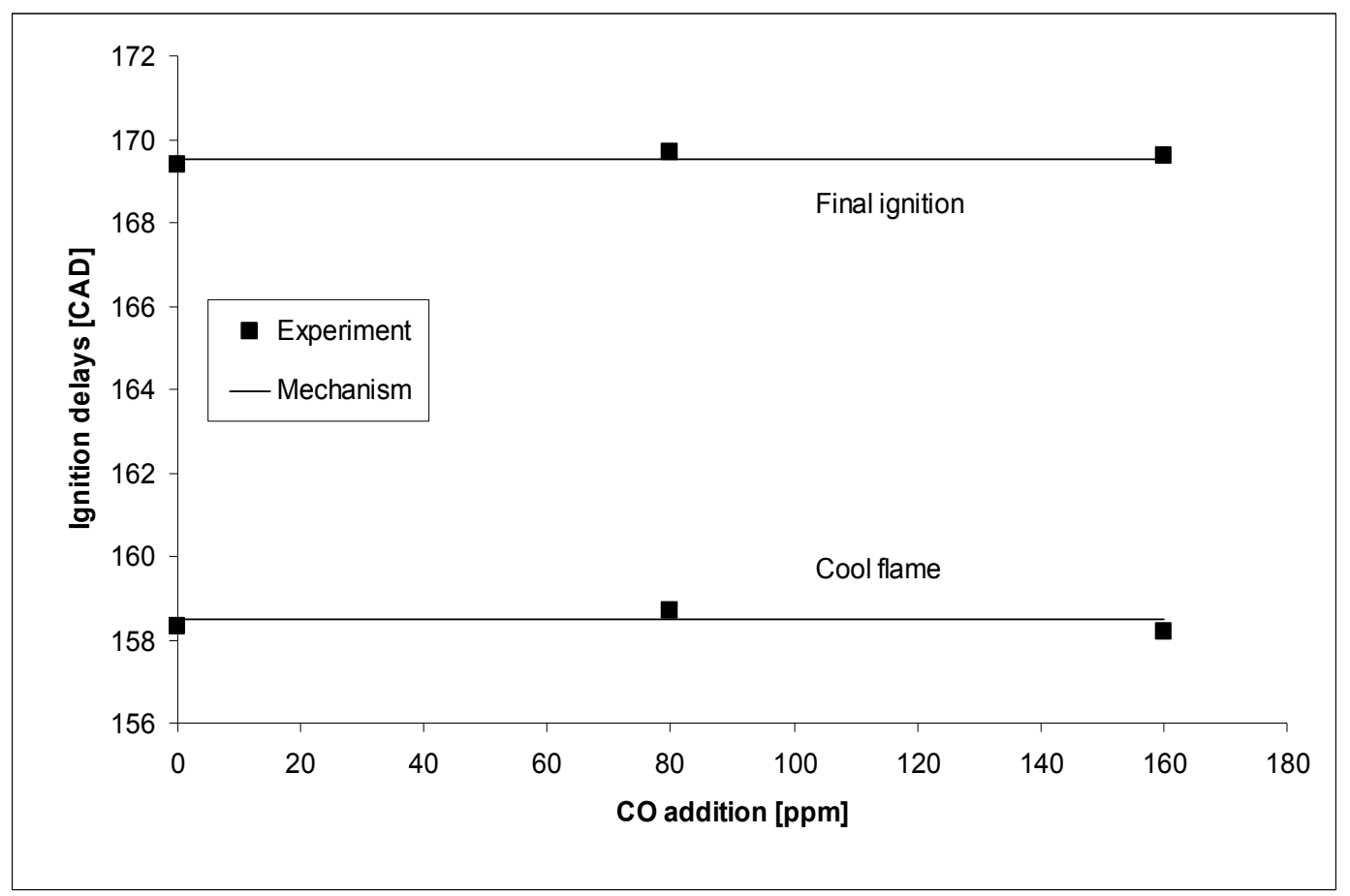

Figure 7: Comparison between modelling ignition delays and experimental ignition delays at an inlet temperature of $70^{\circ} \mathrm{C}$, an equivalence ratio of 0,35 , a compression ratio of 10,2 , nheptane as the fuel, varying the addition of $\mathrm{CO}$ 


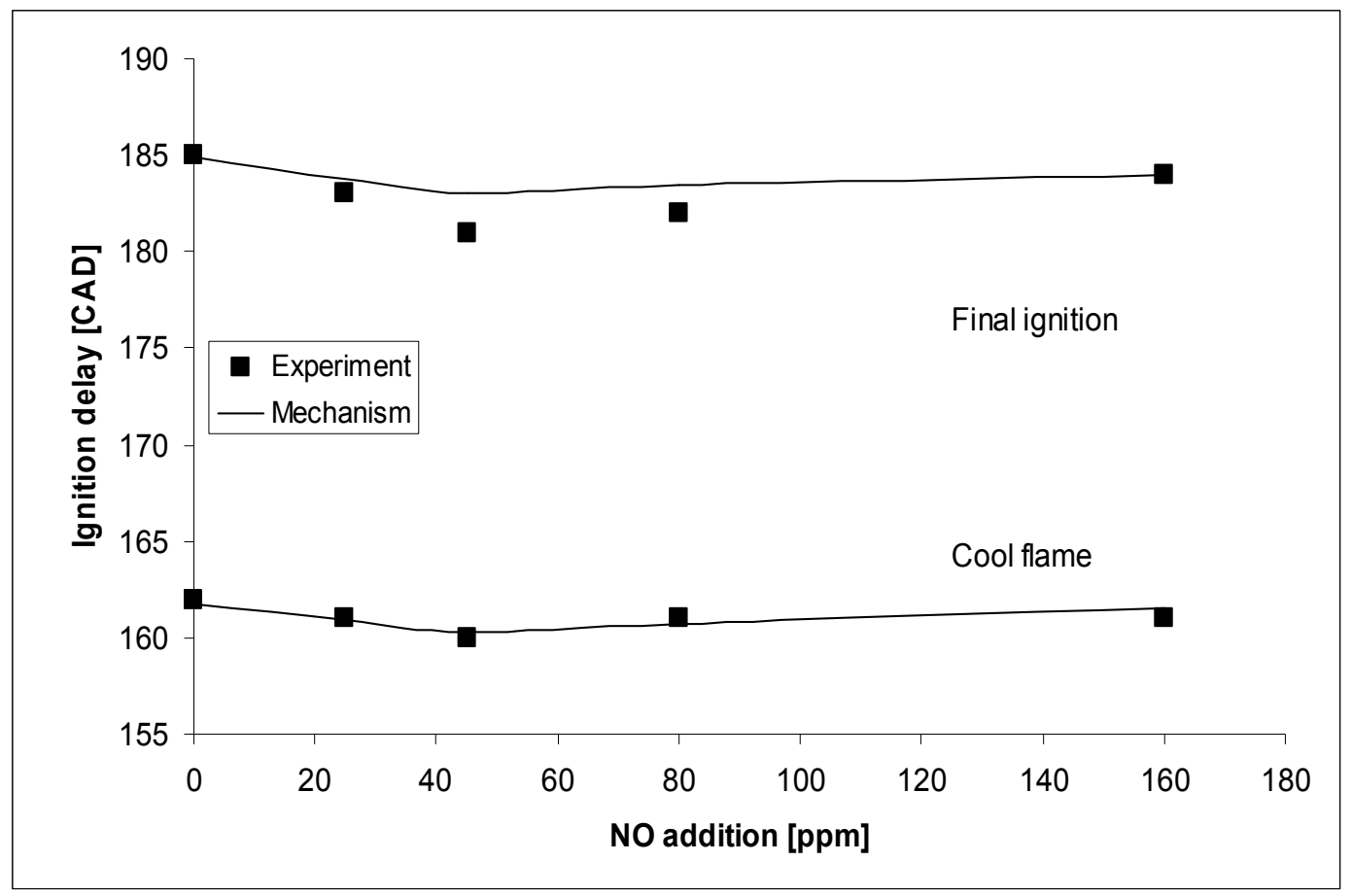

Figure 8: Comparison between modelling ignition delays and experimental ignition delays at an inlet temperature of $70{ }^{\circ} \mathrm{C}$, an equivalence ratio of 0,32 , a compression ratio of 10,2, " 60 vol\% n-heptane / 40 vol\% iso-octane" as the fuel, varying the addition of NO 


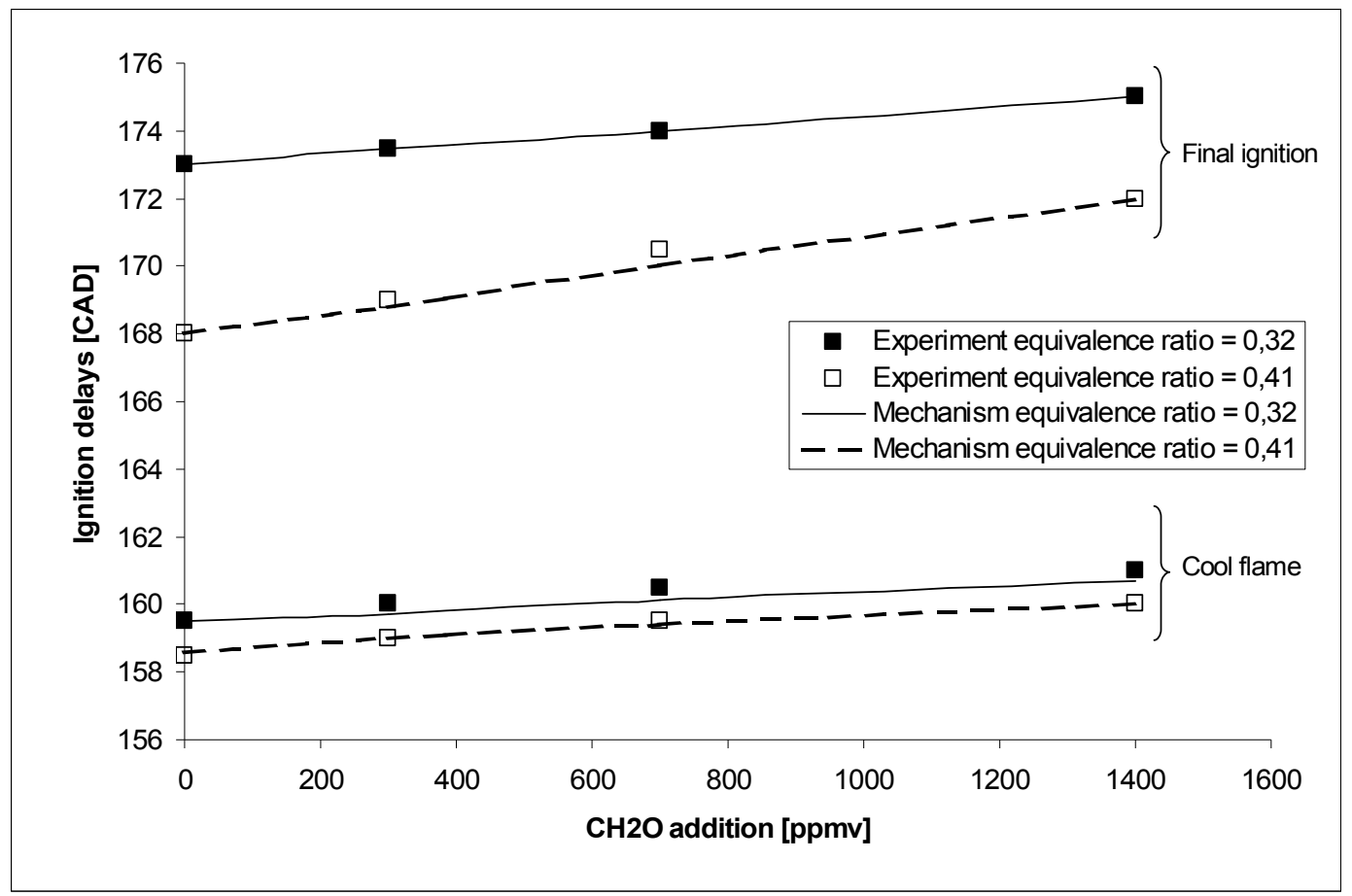

Figure 9: Comparison between modelling ignition delays and experimental ignition delays at an inlet temperature of $70{ }^{\circ} \mathrm{C}$, an equivalence ratio of 0,32 and 0,41 , a compression ratio of 10,2 , "60 vol\% n-heptane / $40 \mathrm{vol} \%$ iso-octane" as the fuel, varying the $\mathrm{CH}_{2} \mathrm{O}$ content in the inlet mixture 


\section{Tables}

Table 1: Reduced kinetic reaction scheme of surrogates of n-heptane, iso-octane and toluene

\begin{tabular}{|c|c|c|c|c|}
\hline \multicolumn{5}{|c|}{$k=A T^{b} \exp \left(-E_{a} / R T\right)$} \\
\hline $\begin{array}{c}\text { Reaction } \\
\text { number }\end{array}$ & Reaction & $\begin{array}{c}\mathrm{A} \\
{[\mathrm{mole}-\mathrm{cm}-\mathrm{s}-\mathrm{K}]}\end{array}$ & $\mathrm{b}[-]$ & Ea $[\mathrm{J} / \mathrm{mole}]$ \\
\hline Reactions & N-heptane initiation reactions & & & \\
\hline 1 & $\mathrm{C} 7 \mathrm{H} 16+\mathrm{O} 2=>\mathrm{C} 7 \mathrm{H} 15-2+\mathrm{HO} 2$ & $2,80 \mathrm{E}+14$ & 0 & 197212,4 \\
\hline 2 & $\mathrm{C} 7 \mathrm{H} 16+\mathrm{OH}=>\mathrm{C} 7 \mathrm{H} 15-2+\mathrm{H} 2 \mathrm{O}$ & $4,80 \mathrm{E}+09$ & 1,3 & 2886,29 \\
\hline 3 & $\mathrm{C} 7 \mathrm{H} 16+\mathrm{HO} 2=>\mathrm{C} 7 \mathrm{H} 15-2+\mathrm{H} 2 \mathrm{O} 2$ & $1,00 \mathrm{E}+13$ & 0 & 70851 \\
\hline 4 & $\mathrm{C} 7 \mathrm{H} 15-2+\mathrm{O} 2=\mathrm{C} 7 \mathrm{H} 15 \mathrm{O} 2$ & $2,00 \mathrm{E}+12$ & 0 & 0 \\
\hline 5 & $\mathrm{C} 7 \mathrm{H} 15 \mathrm{O} 2=\mathrm{C} 7 \mathrm{H} 14 \mathrm{O} 2 \mathrm{H}$ & $6,00 \mathrm{E}+11$ & 0 & 85188,4 \\
\hline 6 & $\mathrm{C} 7 \mathrm{H} 14 \mathrm{O} 2 \mathrm{H}+\mathrm{O} 2=\mathrm{C} 7 \mathrm{H} 14 \mathrm{O} 2 \mathrm{HO} 2$ & $2,34 \mathrm{E}+11$ & 0 & 0 \\
\hline 7 & $\mathrm{C} 7 \mathrm{H} 14 \mathrm{O} 2 \mathrm{HO} 2=>\mathrm{C} 7 \mathrm{KET} 21+\mathrm{OH}$ & $2,97 \mathrm{E}+13$ & 0 & 111606 \\
\hline 8 & $\mathrm{C} 7 \mathrm{KET} 21=>\mathrm{C} 5 \mathrm{H} 11+\mathrm{CO}+\mathrm{CH} 2 \mathrm{O}+\mathrm{OH}$ & $1,00 \mathrm{E}+16$ & 0 & 177232 \\
\hline 9 & $\mathrm{C} 5 \mathrm{H} 11=>\mathrm{C} 2 \mathrm{H} 5+\mathrm{C} 3 \mathrm{H} 6$ & $3,20 \mathrm{E}+13$ & 0 & 118294 \\
\hline 10 & $\mathrm{C} 3 \mathrm{H} 6+\mathrm{OH}=>\mathrm{CH} 3 \mathrm{CHO}+\mathrm{CH} 3$ & $3,50 \mathrm{E}+11$ & 0 & 0 \\
\hline Reactions & Iso-octane initiation reactions & & & \\
\hline 11 & $\mathrm{IC} 8 \mathrm{H} 18+\mathrm{O} 2+\mathrm{O} 2=>\mathrm{R} 2 \mathrm{C} 8 \mathrm{H} 17 \mathrm{OO}+\mathrm{HO} 2$ & $2,10 \mathrm{E}+17$ & 0 & 204820 \\
\hline 12 & $\mathrm{IC} 8 \mathrm{H} 18+\mathrm{OH}=>\mathrm{CC} 8 \mathrm{H} 17+\mathrm{H} 2 \mathrm{O}$ & $2,48 \mathrm{E}+13$ & 0 & 1839,2 \\
\hline 13 & $\mathrm{IC} 8 \mathrm{H} 18+\mathrm{HO} 2=\mathrm{CC} 8 \mathrm{H} 17+\mathrm{H} 2 \mathrm{O} 2$ & $2,02 \mathrm{E}+12$ & 0 & 60192 \\
\hline 14 & $\mathrm{CC} 8 \mathrm{H} 17+\mathrm{O} 2=\mathrm{R} 2 \mathrm{C} 8 \mathrm{H} 17 \mathrm{OO}$ & $2,50 \mathrm{E}+19$ & $-2,5$ & 0 \\
\hline & Reverse reaction & $1,79 \mathrm{E}+13$ & 0 & 103747,6 \\
\hline 15 & $\mathrm{R} 2 \mathrm{C} 8 \mathrm{H} 17 \mathrm{OO}=\mathrm{C} 8 \mathrm{H} 16 \mathrm{OOH}$ & $3,28 \mathrm{E}+12$ & 0 & 119130 \\
\hline & Reverse reaction & $1,80 \mathrm{E}+11$ & 0 & 84018 \\
\hline 16 & $\mathrm{C} 8 \mathrm{H} 16 \mathrm{OOH}+\mathrm{O} 2=\mathrm{R} 2 \mathrm{C} 8 \mathrm{H} 16 \mathrm{OOHOO}$ & $3,52 \mathrm{E}+19$ & $-2,5$ & 0 \\
\hline & Reverse reaction & $7,00 \mathrm{E}+12$ & 0 & 91040,4 \\
\hline 17 & $\mathrm{R} 2 \mathrm{C} 8 \mathrm{H} 16 \mathrm{OOHOO}=>\mathrm{OH}+\mathrm{C} 7 \mathrm{H} 14 \mathrm{CHO}(\mathrm{OOH})$ & $4,80 \mathrm{E}+12$ & 0 & 119130 \\
\hline 18 & $\mathrm{C} 7 \mathrm{H} 14 \mathrm{CHO}(\mathrm{OOH})=>\mathrm{CO}+\mathrm{IC} 6 \mathrm{H} 13+\mathrm{CH} 2 \mathrm{O}+\mathrm{OH}$ & $2,05 \mathrm{E}+15$ & 0 & 173052 \\
\hline 19 & $\mathrm{CC} 8 \mathrm{H} 17+\mathrm{HO} 2=>\mathrm{IC} 6 \mathrm{H} 13+\mathrm{C} 2 \mathrm{H} 3+\mathrm{H} 2 \mathrm{O} 2$ & $2,00 \mathrm{E}+12$ & 0 & 0 \\
\hline 20 & $\mathrm{CC} 8 \mathrm{H} 17=>\mathrm{IC} 4 \mathrm{H} 8+\mid \mathrm{C} 4 \mathrm{H} 9$ & $4,28 \mathrm{E}+12$ & 0 & 115368 \\
\hline 21 & $\mathrm{IC} 6 \mathrm{H} 13=>\mathrm{IC} 3 \mathrm{H} 7+\mathrm{C} 3 \mathrm{H} 6$ & $2,51 \mathrm{E}+13$ & 0 & 117876 \\
\hline 22 & $\mathrm{IC} 4 \mathrm{H} 9+\mathrm{O} 2=>\mathrm{IC} 4 \mathrm{H} 8+\mathrm{HO} 2$ & $1,00 \mathrm{E}+12$ & 0 & 20900 \\
\hline 23 & $\mathrm{IC} 4 \mathrm{H} 8+\mathrm{OH}=>\mathrm{IC} 3 \mathrm{H} 7+\mathrm{CH} 2 \mathrm{O}$ & $1,51 \mathrm{E}+12$ & 0 & 0 \\
\hline 24 & $\mathrm{IC} 3 \mathrm{H} 7+\mathrm{O} 2=>\mathrm{C} 3 \mathrm{H} 6+\mathrm{HO} 2$ & $1,00 \mathrm{E}+12$ & 0 & 20900 \\
\hline 25 & $\mathrm{C} 3 \mathrm{H} 6+\mathrm{OH}=>\mathrm{C} 2 \mathrm{H} 5+\mathrm{CH} 2 \mathrm{O}$ & $1,00 \mathrm{E}+12$ & 0 & 0 \\
\hline Reactions & Toluene initiation reactions & & & \\
\hline 26 & $\mathrm{C} 6 \mathrm{H} 5 \mathrm{CH} 3+\mathrm{O} 2=\mathrm{C} 6 \mathrm{H} 5 \mathrm{CH} 2+\mathrm{HO} 2$ & $3,00 \mathrm{E}+14$ & 0 & 179706,56 \\
\hline 27 & $\mathrm{C} 6 \mathrm{H} 5 \mathrm{CH} 3+\mathrm{OH}=>\mathrm{C} 6 \mathrm{H} 5 \mathrm{CH} 2+\mathrm{H} 2 \mathrm{O}$ & $5,27 \mathrm{E}+13$ & 0 & 10796,94 \\
\hline
\end{tabular}




\begin{tabular}{|c|c|c|c|c|c|}
\hline 28 & \multicolumn{2}{|c|}{$\mathrm{C} 6 \mathrm{H} 5 \mathrm{CH} 2+\mathrm{HO} 2=>\mathrm{C} 6 \mathrm{H} 5 \mathrm{CHO}+\mathrm{H}+\mathrm{OH}$} & $5,00 \mathrm{E}+12$ & 0 & 0 \\
\hline 29 & \multicolumn{2}{|c|}{$\mathrm{C} 6 \mathrm{H} 5 \mathrm{CHO}+\mathrm{OH}=>\mathrm{C} 6 \mathrm{H} 5 \mathrm{CO}+\mathrm{H} 2 \mathrm{O}$} & $2,25 \mathrm{E}+10$ & 1,18 & $-1868,46$ \\
\hline 30 & \multicolumn{2}{|c|}{$\mathrm{C} 6 \mathrm{H} 5 \mathrm{CO}=>\mathrm{C} 6 \mathrm{H} 5+\mathrm{CO}$} & $3,98 \mathrm{E}+14$ & 0 & 122892 \\
\hline 31 & \multicolumn{2}{|c|}{$\mathrm{C} 6 \mathrm{H} 5+\mathrm{O} 2=>\mathrm{C} 6 \mathrm{H} 5 \mathrm{O}+\mathrm{O}$} & $2,60 \mathrm{E}+13$ & 0 & 25581,6 \\
\hline 32 & \multicolumn{2}{|c|}{$\mathrm{C} 6 \mathrm{H} 5 \mathrm{O}=>\mathrm{CO}+\mathrm{C} 5 \mathrm{H} 5$} & $3,76 \mathrm{E}+54$ & $-12,06$ & 310574 \\
\hline 33 & \multicolumn{2}{|c|}{$\mathrm{C} 5 \mathrm{H} 5+\mathrm{O} 2=>\mathrm{C} 5 \mathrm{H} 4 \mathrm{O}+\mathrm{OH}$} & $1,80 \mathrm{E}+12$ & 0,08 & 75240 \\
\hline 34 & \multicolumn{2}{|c|}{$\mathrm{C} 5 \mathrm{H} 4 \mathrm{O}+\mathrm{O}+2 \mathrm{O} 2=>3 \mathrm{CO}+2 \mathrm{HCO}+\mathrm{H} 2 \mathrm{O}$} & $3,60 \mathrm{E}+16$ & 1,45 & $-3586,44$ \\
\hline Reactions & \multicolumn{2}{|c|}{ C2 reactions } & & & \\
\hline 35 & \multicolumn{2}{|c|}{$\mathrm{C} 2 \mathrm{H} 5+\mathrm{O} 2=>\mathrm{C} 2 \mathrm{H} 4+\mathrm{HO} 2$} & $2,00 \mathrm{E}+10$ & 0 & -9196 \\
\hline 36 & \multicolumn{2}{|c|}{$\mathrm{C} 2 \mathrm{H} 4+\mathrm{OH}=>\mathrm{CH} 2 \mathrm{O}+\mathrm{CH} 3$} & $6,00 \mathrm{E}+13$ & 0 & 4012,8 \\
\hline 37 & \multicolumn{2}{|c|}{$\mathrm{C} 2 \mathrm{H} 4+\mathrm{H}=>\mathrm{C} 2 \mathrm{H} 3+\mathrm{H} 2$} & $1,51 \mathrm{E}+07$ & 2 & 25080 \\
\hline 38 & \multicolumn{2}{|c|}{$\mathrm{C} 2 \mathrm{H} 3+\mathrm{O} 2=>\mathrm{CH} 2 \mathrm{O}+\mathrm{HCO}$} & $3,98 \mathrm{E}+12$ & 0 & -1045 \\
\hline 39 & \multicolumn{2}{|c|}{$\mathrm{CH} 3 \mathrm{CHO}+\mathrm{OH}+\mathrm{M}=>\mathrm{CH} 3+\mathrm{CO}+\mathrm{M}+\mathrm{H} 2 \mathrm{O}$} & $1,80 \mathrm{E}+17$ & 0 & 60192 \\
\hline Reactions & \multicolumn{2}{|c|}{ C1 reactions } & & & \\
\hline 40 & \multicolumn{2}{|c|}{$\mathrm{CH} 3+\mathrm{HO} 2=>\mathrm{CH} 3 \mathrm{O}+\mathrm{OH}$} & $4,30 \mathrm{E}+13$ & 0 & 0 \\
\hline 41 & \multicolumn{2}{|c|}{$\mathrm{CH} 3 \mathrm{O}(+\mathrm{M})=\mathrm{CH} 2 \mathrm{O}+\mathrm{H}(+\mathrm{M})$} & $2,00 \mathrm{E}+13$ & 0 & 114615,6 \\
\hline & \multicolumn{2}{|c|}{ Low pressure limit } & $2,34 \mathrm{E}+25$ & $-2,7$ & 127908 \\
\hline 42 & \multicolumn{2}{|c|}{$\mathrm{CH} 2 \mathrm{O}+\mathrm{OH}+\mathrm{O} 2=>\mathrm{H} 2 \mathrm{O}+\mathrm{HO} 2+\mathrm{CO}$} & $6,69 \mathrm{E}+14$ & 1,18 & $-1868,46$ \\
\hline 43 & \multicolumn{2}{|c|}{$\mathrm{CH} 2 \mathrm{O}+\mathrm{O} 2+\mathrm{M}=>\mathrm{H}+\mathrm{CO}+\mathrm{M}+\mathrm{HO} 2$} & $6,20 \mathrm{E}+16$ & 0 & 154660 \\
\hline 44 & \multicolumn{2}{|c|}{$\mathrm{CH} 2 \mathrm{O}+\mathrm{HO} 2=>\mathrm{HCO}+\mathrm{H} 2 \mathrm{O} 2$} & $2,17 \mathrm{E}+11$ & 0 & 33440 \\
\hline 45 & \multicolumn{2}{|c|}{$\mathrm{HCO}+\mathrm{O} 2=>\mathrm{CO}+\mathrm{HO} 2$} & $3,98 \mathrm{E}+12$ & 0 & 0 \\
\hline 46 & \multicolumn{2}{|c|}{$\mathrm{HCO}+\mathrm{M}=\mathrm{H}+\mathrm{CO}+\mathrm{M}$} & $2,50 \mathrm{E}+14$ & 0 & 70232,36 \\
\hline 47 & \multicolumn{2}{|c|}{$\mathrm{CO}+\mathrm{HO} 2=>\mathrm{CO} 2+\mathrm{OH}$} & $1,51 \mathrm{E}+14$ & 0 & 98857 \\
\hline 48 & \multicolumn{2}{|c|}{$\mathrm{CO}+\mathrm{O}=\mathrm{CO} 2$} & $1,80 \mathrm{E}+10$ & 0 & 10190,84 \\
\hline 49 & \multicolumn{2}{|c|}{$\mathrm{CO}+\mathrm{O}+\mathrm{M}=\mathrm{CO} 2+\mathrm{M}$} & $5,89 \mathrm{E}+15$ & 0 & 17138 \\
\hline 50 & \multicolumn{2}{|c|}{$\mathrm{CO}+\mathrm{OH}=\mathrm{CO} 2+\mathrm{H}$} & $3,09 \mathrm{E}+11$ & 0 & 3072,3 \\
\hline \multirow[t]{2}{*}{51} & $\mathrm{CO} 2+$ & & $2,75 E+12$ & 0 & 183209,4 \\
\hline & Revel & & $3,25 \mathrm{E}+11$ & 0 & 153280,6 \\
\hline Reactions & $\mathrm{O} / \mathrm{Hr}$ & & & & \\
\hline 52 & $\mathrm{HO} 2+$ & & $3,22 \mathrm{E}+15$ & 0 & $-6809,22$ \\
\hline 53 & $\mathrm{H} 2+\mathrm{O}$ & & $1,82 \mathrm{E}+10$ & 1 & 37202 \\
\hline 54 & $\mathrm{H} 2 \mathrm{O} 2$ & & $1,00 \mathrm{E}+13$ & 0 & 7524 \\
\hline & Revel & & $2,03 E+13$ & 0 & 145798,4 \\
\hline 55 & $\mathrm{H} 2 \mathrm{O}+$ & & $2,19 \mathrm{E}+16$ & 0 & 438900 \\
\hline & Enhal & & -- & -- & -- \\
\hline & $\mathrm{H} 2 \mathrm{O}$ & 21 & -- & -- & -- \\
\hline & $\mathrm{CO}$ & 2,0 & -- & -- & -- \\
\hline & $\mathrm{H} 2$ & 3,3 & -- & -- & -- \\
\hline 56 & $\mathrm{H}+\mathrm{O} 2$ & & $2,60 \mathrm{E}+19$ & $-1,24$ & 0 \\
\hline
\end{tabular}




\begin{tabular}{|c|c|c|c|c|c|}
\hline 57 & \multicolumn{2}{|c|}{$\mathrm{H}+\mathrm{O} 2=\mathrm{HO} 2$} & $2,07 \mathrm{E}+18$ & $-1,69$ & 3720,2 \\
\hline 58 & \multicolumn{2}{|c|}{$\mathrm{OH}+\mathrm{HO} 2=\mathrm{H} 2 \mathrm{O}+\mathrm{O} 2$} & $1,91 \mathrm{E}+16$ & -1 & 0 \\
\hline 59 & \multicolumn{2}{|c|}{$\mathrm{H}+\mathrm{O} 2=\mathrm{OH}+\mathrm{O}$} & $2,10 \mathrm{E}+15$ & $-0,3$ & 84436 \\
\hline 60 & \multicolumn{2}{|c|}{$\mathrm{OH}+\mathrm{OH}=\mathrm{O}+\mathrm{H} 2 \mathrm{O}$} & $1,50 \mathrm{E}+09$ & 1,14 & 415,492 \\
\hline 61 & \multicolumn{2}{|c|}{$\mathrm{OH}+\mathrm{OH}=\mathrm{H} 2 \mathrm{O} 2$} & $1,00 \mathrm{E}+25$ & $-5,452$ & 12832,6 \\
\hline 62 & \multicolumn{2}{|c|}{$\mathrm{OH}+\mathrm{OH}(+\mathrm{M})=\mathrm{H} 2 \mathrm{O} 2(+\mathrm{M})$} & $7,60 \mathrm{E}+13$ & $-0,37$ & -8151 \\
\hline & \multicolumn{2}{|c|}{ Low pressure limit } & $4,30 \mathrm{E}+18$ & $-0,9$ & -7106 \\
\hline & \multicolumn{2}{|c|}{ TROE coefficients 0,$7346 ; 94 ; 1756 ; 5182$} & -- & -- & -- \\
\hline & \multicolumn{2}{|c|}{ Enhancement factors: } & -- & -- & -- \\
\hline & $\mathrm{H} 2$ & 2,0 & -- & -- & -- \\
\hline & $\mathrm{H} 2 \mathrm{O}$ & 6,0 & -- & -- & -- \\
\hline & $\mathrm{CH} 4$ & 2,0 & -- & -- & -- \\
\hline & $\mathrm{CO}$ & 1,5 & -- & -- & -- \\
\hline & $\mathrm{CO} 2$ & 2,0 & -- & -- & -- \\
\hline & N2 & 0,7 & -- & -- & -- \\
\hline
\end{tabular}


Table 2: The characteristics of the CFR engine

\begin{tabular}{|l|l|}
\hline Compression ratio & $4 \sim 14$ \\
\hline Bore & $82,55 \mathrm{~mm}$ \\
\hline Stroke & $114,5 \mathrm{~mm}$ \\
\hline Displacement volume & $611 \mathrm{~cm} 3$ \\
\hline Engine connecting rod to crank radius ratio & 4,44 \\
\hline Exhaust valve open & $140^{\circ} \mathrm{ATDC}$ \\
\hline Exhaust valve close & $15^{\circ} \mathrm{ATDC}$ \\
\hline Intake valve open & $10^{\circ} \mathrm{ATDC}$ \\
\hline Intake valve close & $146^{\circ} \mathrm{BTDC}$ \\
\hline
\end{tabular}


Table 3: NO submechanism presenting interaction with the fuels

\begin{tabular}{|c|c|c|c|c|}
\hline \multicolumn{5}{|c|}{$k=A T^{b} \exp \left(-E_{a} / R T\right)$} \\
\hline $\begin{array}{c}\text { Reaction } \\
\text { number }\end{array}$ & Reaction & $\begin{array}{c}\mathrm{A} \\
{[\text { mole-cm-s-K] }}\end{array}$ & $\mathrm{b}[-]$ & Ea $[\mathrm{J} / \mathrm{mole}]$ \\
\hline 1 & $\mathrm{~N}+\mathrm{NO}=\mathrm{N} 2+\mathrm{O}$ & $3,500 \mathrm{E}+13$ & 0,0 & 1379 \\
\hline 2 & $\mathrm{~N}+\mathrm{O} 2=\mathrm{NO}+\mathrm{O}$ & $2,650 \mathrm{E}+12$ & 0,0 & 26752 \\
\hline 3 & $\mathrm{~N}+\mathrm{OH}=\mathrm{NO}+\mathrm{H}$ & $7,333 \mathrm{E}+13$ & 0,0 & 4682 \\
\hline 4 & $\mathrm{NO}+\mathrm{HO} 2=\mathrm{NO} 2+\mathrm{OH}$ & $2,100 \mathrm{E}+12$ & 0,00 & -2006 \\
\hline 5 & $\mathrm{NO}+\mathrm{OH}+\mathrm{M}=\mathrm{HONO}+\mathrm{M}$ & $5,100 \mathrm{E}+23$ & $-2,31$ & -284 \\
\hline 6 & $\mathrm{NO} 2+\mathrm{H}=\mathrm{NO}+\mathrm{OH}$ & $1,000 \mathrm{E}+14$ & 0,00 & 1513 \\
\hline 7 & $\mathrm{NO} 2+\mathrm{HO} 2=\mathrm{HONO}+\mathrm{O} 2$ & $6,300 \mathrm{E}+08$ & 1,25 & 20900 \\
\hline 8 & $\mathrm{HONO}+\mathrm{OH}=\mathrm{NO} 2+\mathrm{H} 2 \mathrm{O}$ & $1,26 \mathrm{E}+10$ & 1,00 & 2383 \\
\hline 9 & $\mathrm{CH} 2 \mathrm{O}+\mathrm{NO} 2=\mathrm{HCO}+\mathrm{HONO}$ & $8,00 \mathrm{E}+02$ & 2,77 & 57391 \\
\hline 10 & $\mathrm{CH} 3+\mathrm{NO} 2=\mathrm{CH} 3 \mathrm{O}+\mathrm{NO}$ & $1,51 \mathrm{E}+13$ & 0,0 & 0,0 \\
\hline 11 & $\mathrm{CH} 3 \mathrm{O}+\mathrm{NO} 2=\mathrm{CH} 2 \mathrm{O}+\mathrm{HONO}$ & $6,02 \mathrm{E}+12$ & 0,0 & 9551 \\
\hline 12 & $\mathrm{CH} 3 \mathrm{O} 2+\mathrm{NO}=\mathrm{CH} 3 \mathrm{O}+\mathrm{NO} 2$ & $5,50 \mathrm{E}+11$ & 0,00 & -4983 \\
\hline 13 & $\mathrm{C} 2 \mathrm{H} 5+\mathrm{NO} 2=\mathrm{C} 2 \mathrm{H} 5 \mathrm{O}+\mathrm{NO}$ & $1,00 \mathrm{E}+13$ & 0,0 & 0,0 \\
\hline 14 & $\mathrm{C} 2 \mathrm{H} 5 \mathrm{O}+\mathrm{NO} 2=\mathrm{CH} 3 \mathrm{CHO}+\mathrm{HONO}$ & $4,00 \mathrm{E}+11$ & 0,0 & 0,0 \\
\hline 15 & $\mathrm{C} 2 \mathrm{H} 5 \mathrm{O} 2+\mathrm{NO}=\mathrm{C} 2 \mathrm{H} 5 \mathrm{O}+\mathrm{NO} 2$ & $3,00 \mathrm{E}+12$ & 0,0 & -1496 \\
\hline 16 & $\mathrm{C} 7 \mathrm{H} 15 \mathrm{O} 2+\mathrm{NO}=\mathrm{C} 7 \mathrm{H} 15 \mathrm{O}+\mathrm{NO} 2$ & $1,630 \mathrm{E}+14$ & 0,0 & -2989 \\
\hline 17 & $\mathrm{C} 7 \mathrm{H} 15+\mathrm{NO} 2=\mathrm{C} 7 \mathrm{H} 15 \mathrm{O}+\mathrm{NO}$ & $1,510 \mathrm{E}+13$ & 0,0 & 0,0 \\
\hline 18 & $\mathrm{C} 8 \mathrm{H} 17 \mathrm{O} 2+\mathrm{NO}=\mathrm{C} 8 \mathrm{H} 17 \mathrm{O}+\mathrm{NO} 2$ & $2,590 \mathrm{E}+12$ & 0,0 & 0,0 \\
\hline 19 & $\mathrm{C} 8 \mathrm{H} 17+\mathrm{NO} 2=\mathrm{C} 8 \mathrm{H} 17 \mathrm{O}+\mathrm{NO}$ & $1,5 \mathrm{E}+13$ & 0,0 & 0,0 \\
\hline 20 & $\mathrm{C} 6 \mathrm{H} 5 \mathrm{CH} 2 \mathrm{OO}+\mathrm{NO}=\mathrm{C} 6 \mathrm{H} 5 \mathrm{CH} 2 \mathrm{O}+\mathrm{NO} 2$ & $1,630 e+14$ & 0,0 & -2989 \\
\hline 21 & $\mathrm{C} 6 \mathrm{H} 5 \mathrm{CH} 2+\mathrm{NO} 2=\mathrm{C} 6 \mathrm{H} 5 \mathrm{CH} 2 \mathrm{O}+\mathrm{NO}$ & $1,510 e+13$ & 0,0 & 0,0 \\
\hline
\end{tabular}


Table 4: Experimental domain of validity for the surrogate mechanism with respect to dilution, thermal and chemical EGR parameters

\begin{tabular}{|l|l|}
\hline Parameter & Domain of validity \\
\hline Dilution by $\mathrm{N}_{2}[\mathrm{vol} \%]$ & $0-30$ \\
\hline Dilution by $\mathrm{CO}_{2}[\mathrm{vol} \%]$ & $0-21$ \\
\hline EGR temperature $\left[{ }^{\circ} \mathrm{C}\right]$ & $30-120$ \\
\hline $\mathrm{CO}$ addition $[\mathrm{ppmv}]$ & $0-170$ \\
\hline $\mathrm{NO}$ addition $[\mathrm{ppmv}]$ & $0-25 \& 80-170$ \\
\hline $\mathrm{CH}_{2} \mathrm{O}$ addition $[\mathrm{ppmv}]$ & $0-1400$ \\
\hline
\end{tabular}

